Article

\title{
Sea Buckthorn (Hippophae rhamnoides) Waste Biomass after Harvesting as a Source of Valuable Biologically Active Compounds with Nutraceutical and Antibacterial Potential
}

\author{
Sarmite Janceva ${ }^{1}$, Anna Andersone ${ }^{1,2, *}$, Liga Lauberte ${ }^{1,2}$, Oskars Bikovens ${ }^{1} \mathbb{1}$, Vizma Nikolajeva ${ }^{3}$, \\ Lilija Jashina ${ }^{1,2}$, Natalija Zaharova ${ }^{1,2}$, Galina Telysheva ${ }^{1,+}$, Maris Senkovs ${ }^{3}{ }^{\mathbb{D}}$, Gints Rieksts ${ }^{1}$, \\ Anna Ramata-Stunda ${ }^{3}$ and Jelena Krasilnikova ${ }^{4}$
}

check for updates

Citation: Janceva, S.; Andersone, A.; Lauberte, L.; Bikovens, O.;

Nikolajeva, V.; Jashina, L.; Zaharova, N.; Telysheva, G.; Senkovs, M.;

Rieksts, G.; et al. Sea Buckthorn (Hippophae rhamnoides) Waste Biomass after Harvesting as a Source of Valuable Biologically Active Compounds with Nutraceutical and Antibacterial Potential. Plants 2022, 11, 642. https://doi.org/10.3390/ plants11050642

Academic Editor: Salvatore Antonino Raccuia

Received: 28 January 2022 Accepted: 21 February 2022 Published: 26 February 2022

Publisher's Note: MDPI stays neutral with regard to jurisdictional claims in published maps and institutional affiliations.

Copyright: (C) 2022 by the authors. Licensee MDPI, Basel, Switzerland. This article is an open access article distributed under the terms and conditions of the Creative Commons Attribution (CC BY) license (https:// creativecommons.org/licenses/by/ $4.0 /)$.
1 Laboratory of Lignin Chemistry, Latvian State Institute of Wood Chemistry, Dzerbenes Street 27, LV-1006 Riga, Latvia; sarmite.janceva@kki.lv (S.J.); liga.lauberte@kki.lv (L.L.); oskars.bikovens@kki.lv (O.B.); lilija_jasina@inbox.lv (L.J.); natalija.zaharova@gmail.com (N.Z.); gints.rieksts@inbox.com (G.R.)

2 Ekokompozit Ltd., Dzerbenes Street 27, LV-1006 Riga, Latvia

3 Faculty of Biology, University of Latvia, Jelgavas Street 1, LV-1004 Riga, Latvia; vizma.nikolajeva@lu.lv (V.N.); maris.senkovs@lu.lv (M.S.); anna.ramata-stunda@lu.lv (A.R.-S.)

4 Department of Biochemistry, Riga Stradinš University, Dzirciema Street 16, LV-1007 Riga, Latvia; jelena.krasilnikova@rsu.lv

* Correspondence: anna.andersone@kki.lv; Tel.: +371-29104319

† Sadly, Galina Telysheva passed away in November 2021. As she was the head of the project, and took part in the conceptualization, writing, choice of methodology, and investigation, the rest of the authors decided to submit the paper with her name as co-author. This is our tribute to our dear master. Anna Andersone (2nd author) as a daughter of Galina Telysheva confirms that Galina Telysheva approved the publication, and there is no conflict of interest.

\begin{abstract}
For sustainable sea buckthorn (Hippophae rhamnoides) berry production, the task at hand is to find an application for the large amount of biomass waste arising at harvesting. Sea buckthorn (SBT) vegetation is currently poorly studied. The purpose of this research was to assess the composition and potential of SBT twigs as a source of valuable biologically active substances. Water and $50 \%$ EtOH extracts of twigs of three Latvian SBT cultivars with a high berry yield and quality, popular for cultivation in many countries (H. rhamnoides 'Maria Bruvele', 'Tatiana', 'Botanicheskaya Lubitelskaya'), were investigated for the first time. The phytochemical composition (UHPLC-ESI-MS/MS analysis) and biological activity of the obtained hydrophilic extracts were determined. The highest yield of polyphenolic compounds and serotonin was observed for 'Maria Bruvele'. Hydrophilic extracts were investigated for radical scavenging activity (DPPH' test), antibacterial/antifungal activity against five pathogenic bacteria/yeast, cytotoxicity, and the enzymatic activity of alpha-amylase (via in vitro testing), which is extremely important for the treatment of people with underweight, wasting, and malabsorption. The results showed a high potential of sea buckthorn biomass as a source of valuable biologically active compounds for the creation of preparations for the food industry, nutraceuticals, and cosmetics.
\end{abstract}

Keywords: sea buckthorn twigs; plant secondary metabolites; polyphenols; proanthocyanidins; serotonin; biological activity; antioxidant; antibacterial activity; cytotoxicity; alpha-amylase

\section{Introduction}

SBT (Hippophae rhamnoides L.) is a nitrogen-fixing and pest-resistant deciduous shrub tree which grows widely in Europe and high-altitude cold regions of Asia, and North and South America. Surviving the extreme temperatures (from -40 to $+40{ }^{\circ} \mathrm{C}$ ) $[1,2]$ forces the plant to develop adaptogenic qualities. The plant has evolved a diversified chemical portfolio, and every part of the plant is nutritious, including its leaves, twigs, and even bark $[3,4]$. 
The global SBT berries export market is valued at USD 2 billion. The top exporter in 2020 was Canada, with USD 0.417 billion and yearly increase of $13.9 \%$ [5]. On an industrial scale, SBT is cultivated in Russia, China, Canada, Finland, Germany, Latvia, Romania, and Estonia [6]. The overall market of SBT products is $\sim 17$ times bigger than just for berries and is constantly growing [7]. The industry uses fruits, but there are almost no applications for the green part of SBT [5], which comprises $~ 12-15 \%$ of the harvested mass $[8,9]$.

Varietal characteristics have a significant impact on the quality indicators of raw material [10-12]. The advantages of Latvian SBT varieties are frost resistance, high-quality (large and sweet) fruits, and winter hardiness. Among the varieties exported to different countries, the largest-fruited (0.5-1 g) are H. rhamnoides 'Botanicheskaya Lubitelskaja', 'Prozrachnaya', 'Maria Bruvele', 'Tatiana', 'Avgustinka', 'Perchik', and 'Trofimovskaya' [13-15] (henceforth to be identified as the cultivars 'Botanicheskaya Lubitelskaja', 'Prozrachnaya', 'Maria Bruvele', 'Tatiana', 'Avgustinka', 'Perchik', and 'Trofimovskaya').

SBT fruits are quite well studied in terms of phytochemical composition and application [16-20]. The application of SBT fruit oil and leaf has no side effects [21]. The demand for natural biologically active substances, including antioxidant, antibacterial, and biostimulating substances, replacing harmful chemically synthesized ones, is constantly growing. Plant secondary metabolites possess enormous potential for further uses [22].

Upon harvesting at the production scale, a large amount of SBT biomass waste is produced, as the berries are collected by cutting the whole branch, freezing it, and shaking off the frozen berries. When the plant rests from growing berries, pruning is carried out to rejuvenate the bushes. Finding applications for the SBT biomass waste is necessary for the sustainable use of resources, which is the task of the European Green Deal [1], and for the creation of additional income for SBT growers and workers in rural area.

Sea buckthorn (SBT) is one of the most ancient plants on Earth (older than 2 billion years), and its fruits are mentioned among the most valuable in the world $[8,23,24]$. In recent studies, it was found that the biomass of all parts of the SBT tree also contains practically all biologically active groups of organic compounds currently known and 18 important microelements $[1,25]$. This is why in Latvia SBT is called the Latvian Gold. This makes the biomass of SBT a promising raw material for different branches of the economy [26].

SBT accumulates significant amounts of polyphenolic substances, including flavonols, flavones, phenolic acids, proanthocyanidins (PACs), and hydrolysable tannins, which are reported as the major contributors to antioxidant activities of SBT berries and leaves [17,27], and could be used both for the creation of pharmaceuticals and in the food industry to slow down oxidative processes in raw materials and finished products.

SBT bark contains another valuable secondary metabolite, serotonin [28], which is one of the most interesting and expensive components of SBT extractives. The research on obtaining serotonin from SBT is very limited worldwide.

The chemical structures of serotonin and B-type procyanidin are shown in Figure 1.<smiles>NCCc1c[nH]c2ccc(O)cc12</smiles>

(A)<smiles>Oc1cc(O)c2c(c1)OC(c1ccc(O)c(O)c1)C(O)C2c1c(O)cc(O)c2c1OC(c1ccc(O)c(O)c1)C(O)C2</smiles>

(B)

Figure 1. Chemical structure of serotonin (A) and B-type procyanidin (B), represented by $4-8$ epicatechin dimer. 
The levels of serotonin vary in different plant parts [29]. Serotonin has been implicated in diverse physiological functions in plants such as growth regulation, flowering, xylem sap exudation, ion permeability, plant morphogenesis, and the regulation of abiotic stress tolerance [30]. It also defends plants against fungi [31]. In mammals, serotonin acts as a neurotransmitter in the central nervous system and affects motor activity and the functioning of the gastrointestinal tract. It can be beneficial for treating cancer, HIV, Parkinson-like symptoms, obesity, depression, insomnia, alcohol abuse, schizophrenia, and several chronic diseases [28,32]. The content of serotonin in the bark of SBT is one-thousand times higher than in bananas or chocolate [28]. The antioxidant activity of serotonin far exceeds that of tryptophan, tryptamine, and serotonin derivatives [33]. Furthermore, 95\% of serotonin is produced in the peripheral organs, and serotonin in the digestive system may work independently of serotonin in the brain [34]. In addition to its application in human diets, serotonin could be used as a natural biostimulant for plant rooting [30].

Another important urgent task is the search for natural substances with antibacterial properties and low toxicity to the human body since the resistance to synthetic antibiotics among Gram-positive and Gram-negative bacterial pathogens is growing tremendously. Each year, approximately 25,000 patients in the EU die from infections due to multidrugresistant bacteria [35]. Escherichia coli and Staphylococcus aureus are pathogens that are responsible for the most primary and secondary skin and blood infections. S. aureus also constitutes $30 \%$ of burn wounds. Non-healing wounds are a huge problem for diabetic and older patients [36]. Extracts of the vegetative part of SBT have not yet been studied as antimicrobial agents, although studies on the effect of PACs and quinic acid on the activity of E. coli in cells indicate the possibility of creating antimicrobial agents based on them [37]. Quinic acid inhibits the growth of most microorganisms [38].

An equally important problem is metabolic disorders in the body. There is evidence of the effect of PACs on the activity of the hydrolytic cleavage of carbohydrates to monosaccharides, under the action of $\alpha$-amylase in saliva $[39,40]$. It has been proven that the initial processes of human macro-metabolism are extremely important, and saliva plays a major physiologic role in food digestion [41]. Studies have linked higher amylase levels to better glucose tolerance after eating starch-rich meals [42,43]. PAC-containing extracts, based on the concentration of the active substance, can both activate and inhibit the activity of amylase in the initial breakdown of carbohydrates. Therefore, the possibility of using SBT twig extracts for the normalization of the enzymatic activity of saliva can be studied.

Taking into account the relevance of the topic of the complex and rational use of plant raw materials, and the insufficient amount of knowledge about SBT biomass, the aim of this study was to assess the potential of pruned SBT twigs, as waste after SBT berries harvesting, of three the most prospective cultivars of SBT ('Maria Bruvele', 'Tatiana', and 'Botanicheskaya Lubitelskaya') as a source of valuable biologically active substances, mainly polyphenols and serotonin, with the establishment of the phytochemical composition and biological activity (antioxidant, antibacterial, and enzymatic) of the obtained hydrophilic extracts to determine their practical significance.

\section{Results and Discussion}

\subsection{Yield and Chemical Composition of Hydrophilic Extracts}

A review of the published literature data [44] and our preliminary experiments [45,46] showed that ethanol $(\mathrm{EtOH})$ and its aqueous solutions are the most suitable extraction solvents for the isolation of biologically active polyphenolic compounds from plant biomass, including SBT biomass. For the study of three SBT cultivars ('Maria Bruvele'; 'Tatiana'; and 'Botanicheskaya Lubitelskaya' - Bot. Lub.'), 50\% EtOH and distilled water were used as extractants for hydrophilic extract isolation, based on their selectivity for polyphenolic compounds, chemical inertness, low toxicity, and low cost. The quantitative analysis of the total polyphenolic compounds was performed for the obtained extracts, determining the effect of extractant concentration on the efficiency of polyphenolic compound release (Figure 1). The yield of hydrophilic extracts was determined by the gravimetric method 
after the freeze-drying of the samples. The yield of hydrophilic extracts (hereinafter extracts) from twigs of three SBT cultivars varied from $15 \%$ to $30 \%$ in terms of dry SBT biomass (Figure 1). The obtained extracts were rich in polyphenolic compounds that are known to be responsible for free radical scavenging activity. The 'Maria Bruvele' biomass had the highest yield of 50\% EtOH extract (30\% from o.d. biomass) and the highest content of phenolic compounds in the extracts (48.1 GAE g/100 g extract or $14.4 \%$ on o.d. biomass with confidence interval $\mathrm{CI}=0.2$ at $\alpha=0.05$ ). Despite the high content of the total polyphenols in 50\% EtOH and water extracts of 'Tatiana' (41.3 and 35.1 GAE g/100 g extract, CI = 0.2 at $\alpha=0.05)$, the yield of the extracts themselves, compared to 'Maria Bruvele', was 2 times less (15 and $16 \%$ on o.d. extract, with $\mathrm{CI}=0.4$ at $\alpha=0.05)$, which reduced the yield of polyphenols from SBT biomass $(6.2 \%$ and $5.6 \%$ on o.d. biomass). Based on these observations, 'Maria Bruvele' is the raw material with the most potential between the 3 investigated popular cultivars for obtaining polyphenol-rich extracts, which has also been confirmed by other authors by examining the chemical composition of sea buckthorn twigs grown in Poland [16]. The contents of total polyphenolic compounds of all the extracts are given in Figure 2.

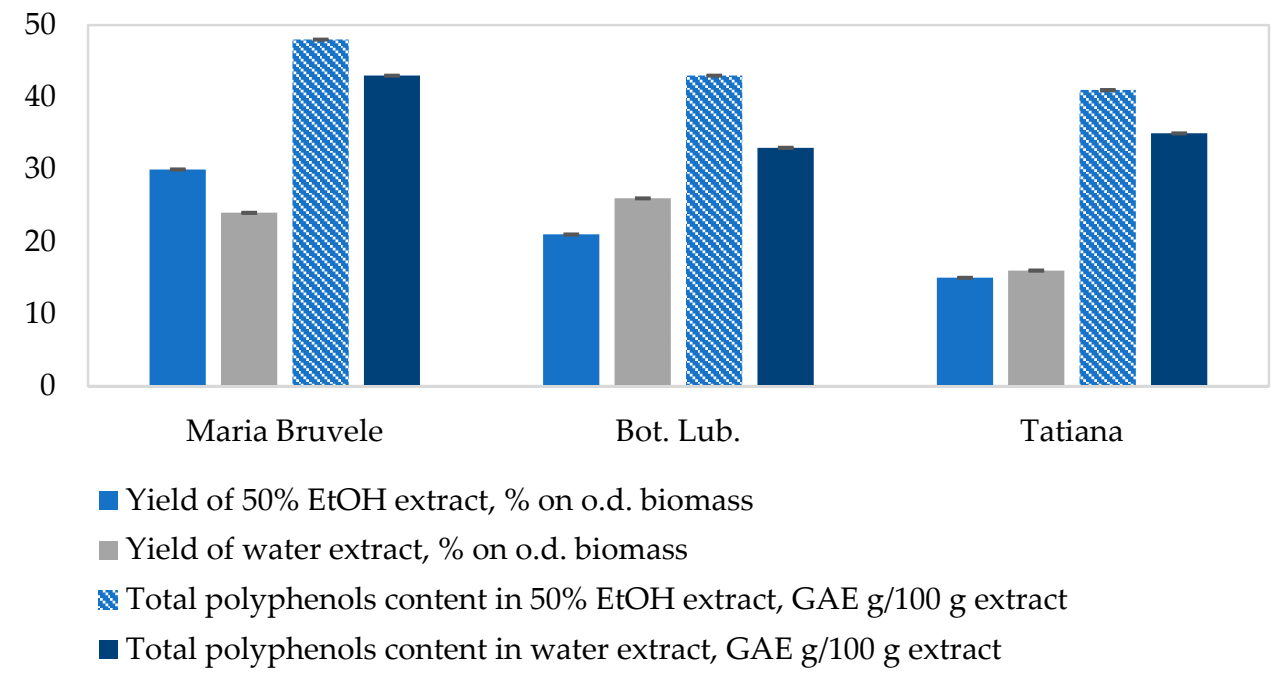

Figure 2. Effect of the extractants on the extract yield from twigs of SBT and selectivity for polyphenolic compounds (single-step extraction, $30 \mathrm{~min}, 60{ }^{\circ} \mathrm{C}$, biomass and extractant weight ratio 1:8). Data represented as mean $\pm \mathrm{SD}(n=3)$.

The freeze-dried 50\% EtOH and water extracts were analyzed by UHPLC-ESI-MS/MS for the identification of biologically active compounds, including polyphenolic compounds, representing a significant part of the extract. UHPLC-ELS chromatograms of extracts are shown in Figures 3 and 4.

The compounds identified are listed in Table 1, with the most abundant ones being quinic acid, catechin/epicatechin, gallocatechin, procyanidin trimer, procyanidin tetramer, (epi)catechin-(epi)gallocatechin, quercetin, quercetin-3-O-rutinoside, triterpenoids, and acylated triterpenoids. Part of the polyphenolic compounds in the extracts is in the form of O-glycosides, which consist of a residue of aglycone and carbohydrates consisting mainly of glucose. At the same time, the compositional similarity of the composition of the $50 \%$ $\mathrm{EtOH}$ and water extracts of the branches of all three varieties of sea buckthorn was found. All these compounds are biologically active natural antioxidants and antimicrobial agents, which can be used as ingredients in the formulation of different medications. 

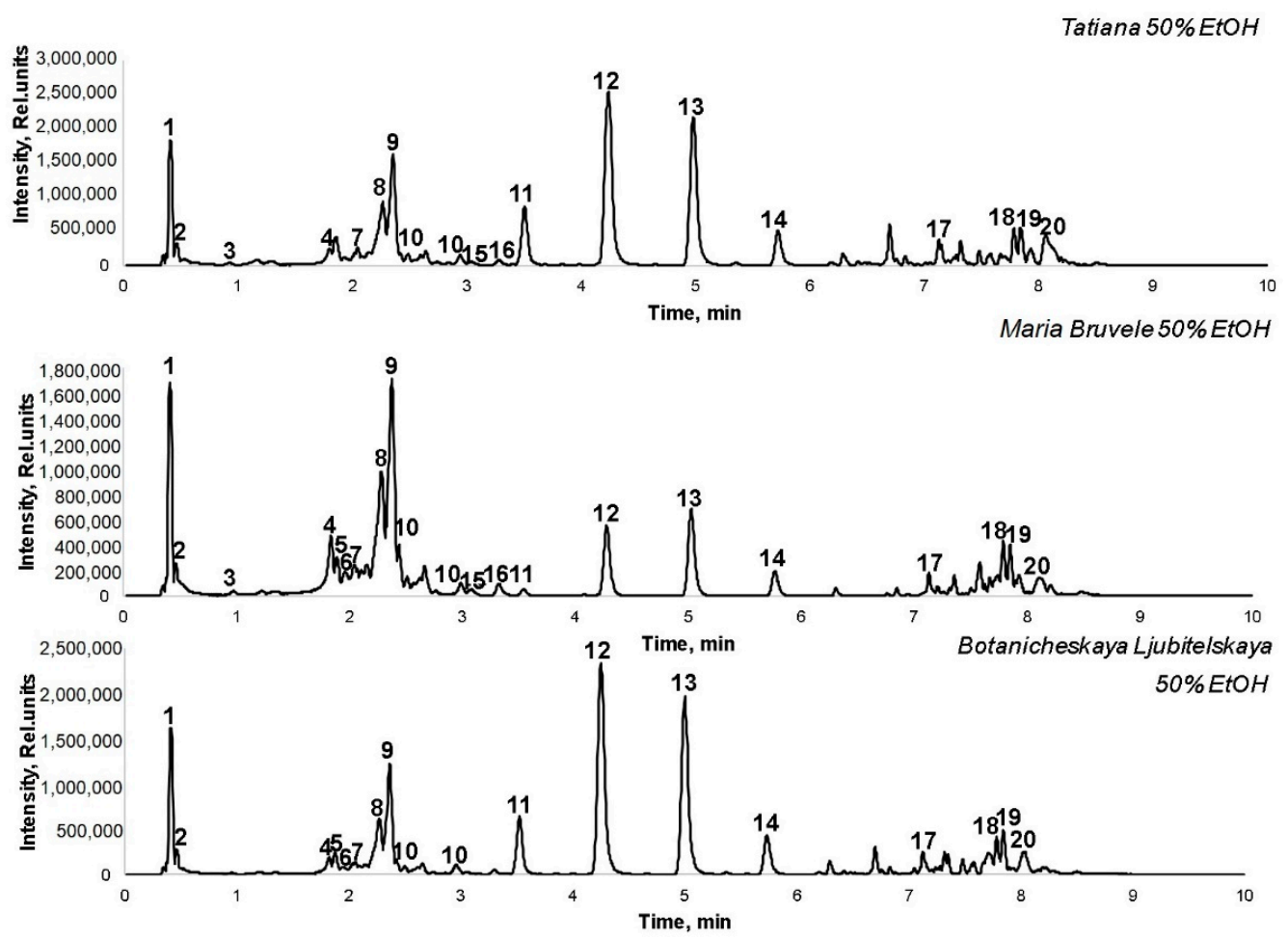

Figure 3. UHPLC-TOF/MS chromatograms of 50\% EtOH extracts of SBT samples.
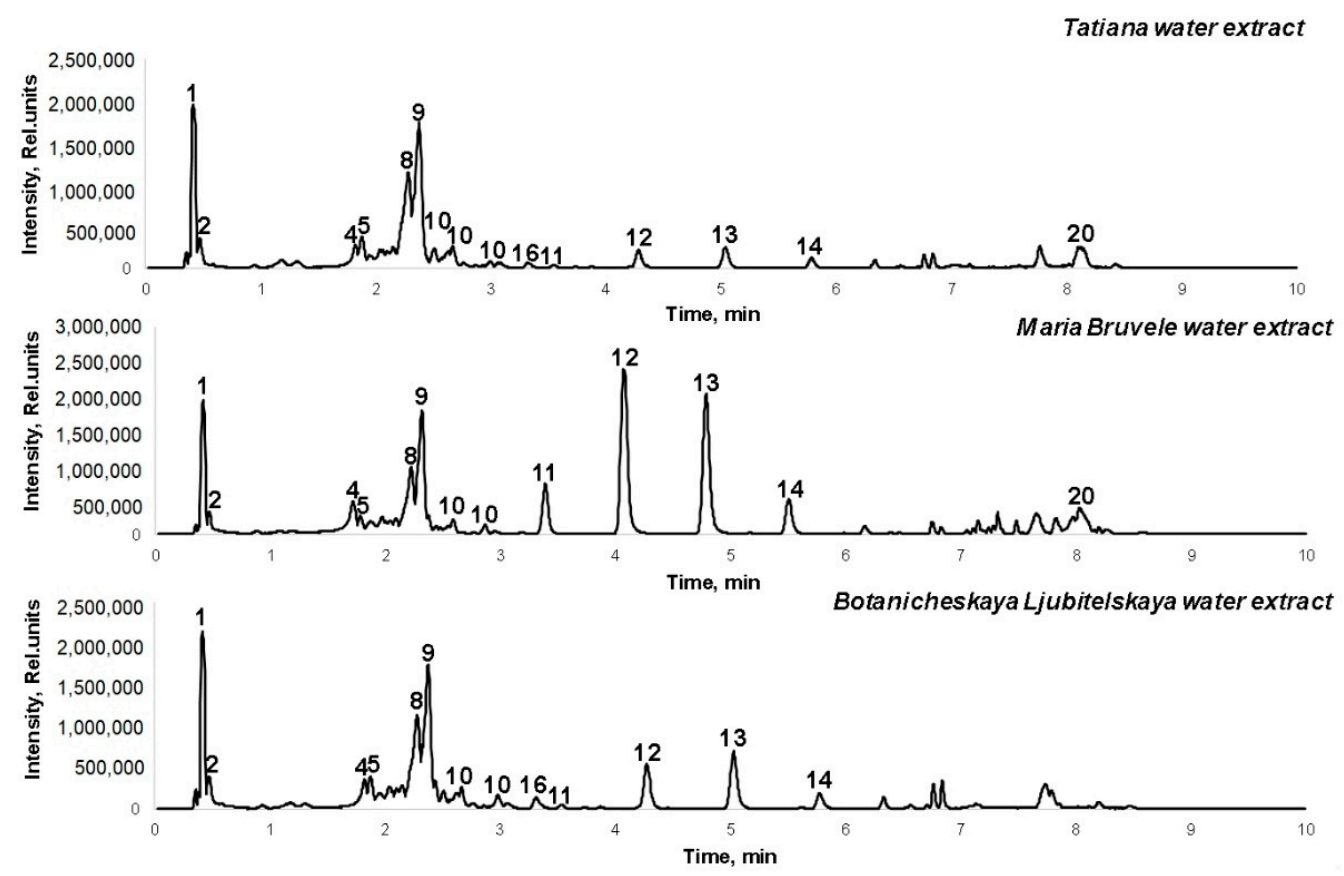

Figure 4. UHPLC-TOF/MS chromatograms of the water extracts of SBT samples.

Among the identified polyphenolics compounds, quinic acid, quercetin, and triterpenoids have documented excellent antibacterial activity against Staphylococcus aureus, which is a leading Gram-positive pathogen associated with a number of diseases, including osteomyelitis, pneumonia, endocarditis, and septicemia. This bacterium is also frequently found in many food products such as dairy, eggs, seafood, and meat, and can cause food poisoning, which is a major concern for the international community and the food industry. Additionally, they show antibacterial activity toward Staphylococcus epidermidis, Bacillus subtilis, and Escherichia coli [37]. 
Table 1. Dominant compounds in the chromatograms of SBT twigs.

\begin{tabular}{|c|c|c|c|c|c|c|c|c|c|c|}
\hline \multirow[b]{3}{*}{ Peak No. } & \multirow[b]{3}{*}{$t^{R}(\min )$} & \multirow[b]{3}{*}{$\begin{array}{c}{[\mathbf{M}-} \\
\mathrm{H}]^{-}(\mathrm{m} / \mathbf{z})\end{array}$} & \multirow[b]{3}{*}{ Fragments } & \multirow[b]{3}{*}{ Identification $^{1}$} & \multicolumn{6}{|c|}{ Relative Abundance, $\%$} \\
\hline & & & & & \multicolumn{2}{|c|}{ Tatiana } & \multicolumn{2}{|c|}{ Maria Bruvele } & \multicolumn{2}{|c|}{ Bot. Lub. } \\
\hline & & & & & Water & $\begin{array}{c}50 \% \\
\text { EtOH }\end{array}$ & Water & $\begin{array}{c}50 \% \\
\text { EtOH }\end{array}$ & Water & $\begin{array}{c}50 \% \\
\text { EtOH }\end{array}$ \\
\hline 1 & 0.41 & 341 & $\begin{array}{l}179 ; 161 ; 143 \\
119 ; 113 ; 101\end{array}$ & $\begin{array}{l}\text { Sucrose, fructose, } \\
\text { glucose }\end{array}$ & 9.7 & 9.0 & 10.7 & 8.2 & 10.9 & 9.3 \\
\hline 2 & 0.47 & 191 & $\begin{array}{l}111 ; 173 \\
127 ; 85\end{array}$ & Quinic acid & 5.7 & 4.4 & 6.1 & 5.0 & 5.6 & 4.2 \\
\hline 3 & 0.98 & 175 & $159 ; 147$ & Serotonin $^{2}$ & 0.1 & 0.1 & 0.1 & 0.1 & 0.1 & 0.1 \\
\hline 4 & 1.84 & 305 & $179 ; 125$ & $\begin{array}{c}\text { Gallocatechin or its } \\
\text { isomer epigallocatechin }\end{array}$ & 0.7 & 1.8 & 2.6 & 1.7 & 3.2 & 1.5 \\
\hline 5 & 1.89 & 593 & $\begin{array}{l}407 ; 425 ; 305 \\
\quad 467 ; 289\end{array}$ & $\begin{array}{c}\text { (epi)catechin- } \\
\text { (epi)gallocatechin }\end{array}$ & 2.2 & 0.5 & 0.9 & 1.1 & 1.3 & 0.4 \\
\hline 6 & 1.97 & 1185 & $\begin{array}{l}881 ; 593 ; 305 \\
289 ; 245\end{array}$ & Procyanidin tetramer & 4.1 & 2.2 & 2.6 & 1.0 & 2.8 & 1.7 \\
\hline 7 & 2.06 & 1055 & $\begin{array}{l}881 ; 593 \\
305 ; 289\end{array}$ & Procyanidin tetramer & 4.4 & 1.8 & 4.6 & 2.7 & 4.4 & 2.3 \\
\hline 8 & 2.30 & 865 & $577 ; 289 ; 245$ & Procyanidin trimer & 4.1 & 4.5 & 5.2 & 4.9 & 4.2 & 3.4 \\
\hline 9 & 2.38 & 289 & $245 ; 125$ & Catechin/Epicatechin & 6.9 & 5.3 & 6.7 & 8.1 & 7.0 & 4.2 \\
\hline 10 & 2.50 & 1153 & $\begin{array}{l}865 ; 577 ; \\
289 ; 245\end{array}$ & Procyanidin tetramer & 13.5 & 13.0 & 9.6 & 12.2 & 17.2 & 7.0 \\
\hline 11 & 3.51 & 610 & - & $\begin{array}{l}\text { Contaminant from } \\
\text { solvent-ethanol, } \\
\text { nylon filter }\end{array}$ & 0.1 & 1.4 & 1.7 & 0.7 & 0.1 & 1.1 \\
\hline 12 & 4.28 & 723 & - & $\begin{array}{l}\text { Contaminant from } \\
\text { solvent-ethanol, } \\
\text { nylon filter }\end{array}$ & 0.6 & 5.2 & 7.2 & 1.3 & 1.0 & 5.6 \\
\hline 13 & 5.04 & 836 & - & $\begin{array}{l}\text { Contaminant from } \\
\text { solvent-ethanol, } \\
\text { nylon filter }\end{array}$ & 0.6 & 4.6 & 6.5 & 1.8 & 1.4 & 5.2 \\
\hline 14 & 5.77 & 949 & - & $\begin{array}{l}\text { Contaminant from } \\
\text { solvent-ethanol, } \\
\text { nylon filter }\end{array}$ & 0.3 & 1.1 & 1.8 & 0.6 & 0.4 & 1.3 \\
\hline 15 & 3.28 & 609 & $301 ; 271$ & $\begin{array}{l}\text { Quercetin-3-O- } \\
\text { rutinoside }\end{array}$ & - & - & - & 0.01 & - & - \\
\hline 16 & 3.33 & 301 & $286 ; 109$ & Quercetin & 0.1 & 0.1 & 0.2 & 0.4 & 0.1 & 0.1 \\
\hline 17 & 7.14 & 487 & $293 ; 117$ & Triterpenoid & - & 2.8 & 3.0 & 2.5 & - & 3.0 \\
\hline 18 & 7.79 & 471 & $452 ; 265 ; 117$ & Triterpenoid & - & 1.8 & - & 3.1 & - & 2.1 \\
\hline 19 & 7.86 & 471 & $265 ; 117$ & Triterpenoid & - & 1.9 & - & 1.8 & - & 2.4 \\
\hline 20 & 8.07 & 455 & $277 ; 117$ & Triterpenoid & 3.2 & 3.4 & 7.2 & 4.3 & - & - \\
\hline 21 & 8.01 & 617 & $255 ; 117$ & Acylated triterpenoid & - & - & - & - & - & 2.8 \\
\hline
\end{tabular}

${ }^{1}$ Serotonin showed weak signal in negative ion ESI LC-MS, which was quantified in MRM positive ionization mode. ${ }^{2}$ Compounds were tentatively identified compared with those reported in the literature and confirmed through databases, specifically the Dictionary of Natural Products and ChemSpider, focusing on MS/MS fragmentation patterns and accurate mass.

A comparison of the relative peak areas of the dominant biologically active compounds calculated for $\mathrm{mg} / \mathrm{mg}$ extract is shown in Table 2. 
Table 2. The comparison of relative peak areas of dominant biologically active compounds calculated on $\mathrm{mg} / \mathrm{mg}$ extract.

\begin{tabular}{|c|c|c|c|c|}
\hline \multirow{2}{*}{ No. } & \multirow{2}{*}{ Tentative Identification } & \multicolumn{2}{|c|}{ Relative Peak Area (Relative Units) } & \multirow{2}{*}{ Cultivar } \\
\hline & & $50 \% \mathrm{EtOH}$ & $\mathrm{H}_{2} \mathrm{O}$ & \\
\hline \multirow{3}{*}{1} & \multirow{3}{*}{ Quinic acid } & 25,954 & 31,176 & Tatiana \\
\hline & & 43,608 & 53,949 & Maria Bruvele \\
\hline & & 38,504 & 44,680 & Bot. Lub. \\
\hline \multirow{3}{*}{2} & \multirow{3}{*}{$\begin{array}{c}\text { Gallocatechin or its isomer } \\
\text { epigallocatechin }\end{array}$} & 14,917 & 11,890 & Maria Bruvele \\
\hline & & 2369 & 4476 & Tatiana \\
\hline & & 5291 & 8424 & Bot. Lub. \\
\hline \multirow{3}{*}{3} & \multirow{3}{*}{$\begin{array}{l}\text { (epi)catechin- } \\
\text { (epi)gallocatechin }\end{array}$} & 6283 & 2855 & Maria Bruvele \\
\hline & & 4782 & 5539 & Tatiana \\
\hline & & 5314 & 6759 & Bot. Lub. \\
\hline \multirow{3}{*}{4} & \multirow{3}{*}{ Procyanidin tetramer } & 8054 & 3230 & Maria Bruvele \\
\hline & & 1674 & 4395 & Tatiana \\
\hline & & 5335 & 5841 & Bot. Lub. \\
\hline \multirow{3}{*}{5} & \multirow{3}{*}{ Procyanidin tetramer } & 8879 & 2397 & Maria Bruvele \\
\hline & & - & 4665 & Tatiana \\
\hline & & - & 7803 & Bot. Lub. \\
\hline \multirow{3}{*}{6} & \multirow{3}{*}{ Procyanidin trimer } & 37,952 & 31,036 & Maria Bruvele \\
\hline & & 15,879 & 26,104 & Tatiana \\
\hline & & 19,967 & 33,381 & Bot. Lub. \\
\hline \multirow{3}{*}{7} & \multirow{3}{*}{ Catechin/Epicatehin } & 51,282 & 56,089 & Maria Bruvele \\
\hline & & 24,115 & 34,058 & Tatiana \\
\hline & & 35,098 & 46,065 & Bot. Lub. \\
\hline \multirow{3}{*}{8} & & 3004 & 1739 & Maria Bruvele \\
\hline & Procyanidin tetramer & 916 & 3500 & Tatiana \\
\hline & & 1864 & 3656 & Bot. Lub. \\
\hline & & 9768 & 5576 & Maria Bruvele \\
\hline 9 & Procyanidin tetramer & 2897 & 6506 & Tatiana \\
\hline & & 4632 & 7877 & Bot. Lub. \\
\hline & & 635 & 2850 & Maria Bruvele \\
\hline 10 & Procyanidin tetramer & 236 & 619 & Tatiana \\
\hline & & 382 & 751 & Bot. Lub. \\
\hline & & 1348 & 973 & Maria Bruvele \\
\hline 11 & Procyanidin tetramer & 1893 & 1023 & Tatiana \\
\hline & & 2946 & 3040 & Bot. Lub. \\
\hline & & 334 & - & Maria Bruvele \\
\hline 12 & Quercetin-3-O-rutinoside & - & - & Tatiana \\
\hline & & - & - & Bot. Lub. \\
\hline & & 2759 & 677 & Maria Bruvele \\
\hline 13 & Quercetin & 933 & 1003 & Tatiana \\
\hline & & 1287 & 3105 & Bot. Lub. \\
\hline & & 3218 & - & Maria Bruvele \\
\hline 14 & Triterpenoid & 3750 & - & Tatiana \\
\hline & & 4561 & - & Bot. Lub. \\
\hline & & 7631 & - & Maria Bruvele \\
\hline 15 & Triterpenoid & 5000 & - & Tatiana \\
\hline & & 6950 & - & Bot. Lub. \\
\hline & & 7273 & - & Maria Bruvele \\
\hline 16 & Triterpenoid & 5860 & - & Tatiana \\
\hline & & 8651 & - & Bot. Lub. \\
\hline & & 4923 & 14,713 & Maria Bruvele \\
\hline 17 & Triterpenoid & 8978 & 6910 & Tatiana \\
\hline & & - & - & Bot. Lub. \\
\hline & & - & - & Maria Bruvele \\
\hline 18 & Acylated triterpenoid & - & - & Tatiana \\
\hline & & 6808 & - & Bot. Lub. \\
\hline
\end{tabular}




\subsection{Evaluation of the Antimicrobial Activity of SBT Extracts}

The evaluation of the antimicrobial activity of the plant extracts against test cultures of microorganisms was carried out according to the method for determining the sensitivity of microorganisms to antimicrobial drugs. Antimicrobial activity was studied in 96-well plates by the two-fold serial broth microdilution method, which allowed the determination of the minimum inhibitory (MIC) and minimum bactericidal/fungicidal concentrations (MBC/MFC) [47].

The comparison of the results of the chemical composition and antimicrobial activity of $50 \%$ EtOH extracts showed that among the three varieties of SBT, 'Maria Bruvele' was the most active in suppressing pathogenic bacteria. This could be explained by the increased content of such biologically active compounds as quinic acid, gallocatechin, isomer epigallocatechin, (epi)catechin-(epi)gallocatechin, and procyanidins.

The results show that all extracts have high antimicrobial activity against both Grampositive and Gram-negative bacteria (see Table 3).

Table 3. Antimicrobial activity of the extracts from SBT samples.

\begin{tabular}{|c|c|c|c|c|c|c|}
\hline & Maria Bruvele & Bot. Lub. & Tatiana & Maria Bruvele & Bot. Lub. & Tatiana \\
\hline & \multicolumn{3}{|c|}{$50 \%$ EtOH Extract, $\mathrm{mg} / \mathrm{mL}$} & \multicolumn{3}{|c|}{ Water Extract, mg/mL } \\
\hline $\begin{array}{c}\text { E. coli } \\
\mathrm{MIC} / \mathrm{MBC}\end{array}$ & $0.20 / 0.20$ & $0.39 / 0.39$ & $0.39 / 0.39$ & $0.39 / 0.39$ & $0.78 / 50$ & $0.39 / 0.39$ \\
\hline $\begin{array}{l}\text { P. aeruginosa } \\
\text { MIC/MBC }\end{array}$ & $0.39 / 0.78$ & $0.78 / 1.56$ & $3.13 / 3.13$ & $0.39 / 3.13$ & $0.78 / 50$ & $0.78 / 1.56$ \\
\hline $\begin{array}{l}\text { S. aureus } \\
\text { MIC/MBC }\end{array}$ & $0.20 / 0.39$ & $0.39 / 0.78$ & $0.20 / 0.78$ & $0.39 / 0.78$ & $0.39 / 12.2$ & $0.39 / 0.78$ \\
\hline $\begin{array}{l}\text { B. cereus } \\
\text { MIC/MBC }\end{array}$ & $0.39 / 50$ & $0.78 />50$ & $0.78 / 50$ & $0.78 />50$ & $0.78 />50$ & $0.78 / 50$ \\
\hline $\begin{array}{l}\text { C. albicans } \\
\text { MIC/MFC }\end{array}$ & $0.20 />50$ & $0.20 />50$ & $0.39 />50$ & $0.20 />50$ & $0.39 />50$ & $0.39 />50$ \\
\hline
\end{tabular}

\section{Antibiotics}

Gentamicin (Reference), $\mu \mathrm{g} / \mathrm{mL} \quad$ Fluconazole (Reference), $\mu \mathrm{g} / \mathrm{mL}$ $\mathrm{mg} / \mathrm{mL}$

\begin{tabular}{cccc}
\hline $\begin{array}{c}\text { E. coli } \\
\text { MIC/MBC }\end{array}$ & $1.00 / 4.00$ & $\mathrm{ND}$ & 0.76 \\
\hline $\begin{array}{c}\text { P. aeruginosa } \\
\text { MIC/MBC }\end{array}$ & $0.25 / 4.00$ & $\mathrm{ND}$ & $\mathrm{ND}$ \\
\hline $\begin{array}{c}\text { S. aureus } \\
\text { MIC/MBC }\end{array}$ & $0.25 / 4.00$ & $\mathrm{ND}$ & 1.52 \\
\hline $\begin{array}{c}\text { B. cereus } \\
\text { MIC/MBC }\end{array}$ & $\mathrm{ND}$ & $\mathrm{ND}$ & 0.76 \\
\hline $\begin{array}{c}\text { C. albicans } \\
\text { MIC/MFC }\end{array}$ & $\mathrm{ND}$ & $32 />256$ & $\mathrm{ND}$ \\
\hline
\end{tabular}

MIC-minimum inhibitory concentration; MBC-minimum bactericidal concentration. MFC-minimum fungicidal concentration; ND—not determined. MIC tests were performed in triplicate for each strain and antimicrobial compound. Confidence interval is \pm 0.01 at $\alpha=0.05$.

When comparing the $50 \% \mathrm{EtOH}$ and water extract of SBT 'Maria Bruvele', we found that despite the fact that the content of quinic acid in the water extract was 1.24 times higher, the $50 \% \mathrm{EtOH}$ extract was more active; this could be attributed to the synergetic activity with the other antimicrobial agents, namely, an increased amount of such polyphenolic compounds as gallocatechin or isomer epigallocatechin (1.25 times higher in the $50 \% \mathrm{EtOH}$ extract), (epi)catechin-(epi)gallocatechin (1.13 times higher) and procyanidins (2.5 times higher). 
The minimum bactericidal concentration of the extracts showed that the extracts were able to completely neutralize the bacteria under study, and their MICs were even comparable with those of weaker antibiotics.

\subsection{Evaluation of the Cytotoxicity of Extracts}

The graphs below show the results of the cytotoxicity tests, by changes in cell viability and $\mathrm{IC}_{50}$ values. It was reasonable to evaluate the cytotoxicity around the range of the antimicrobial activity of the extracts. The testing started from lower concentrations of $0.078 \mathrm{mg} / \mathrm{mL}$ up to $10 \mathrm{mg} / \mathrm{mL}$ (Figure 5). The use of higher concentrations made it difficult to read the results objectively as the intensive coloring influenced the absorbance.

A

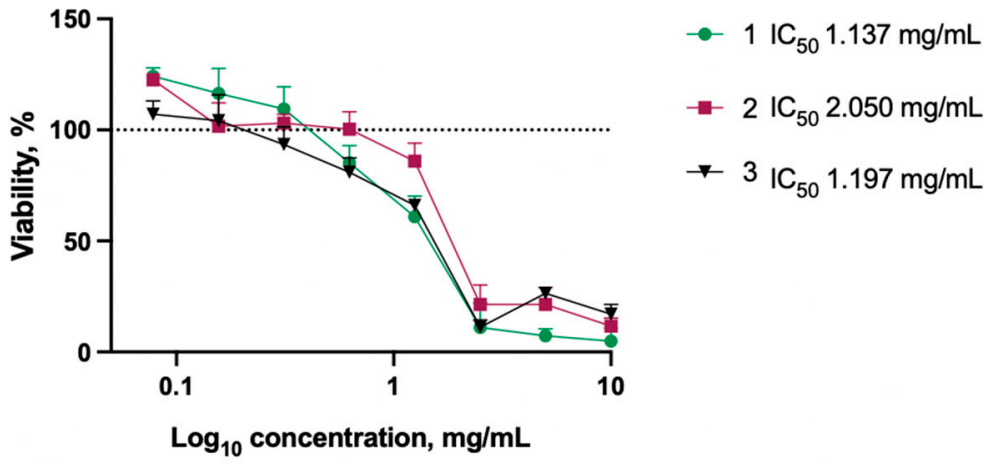

B

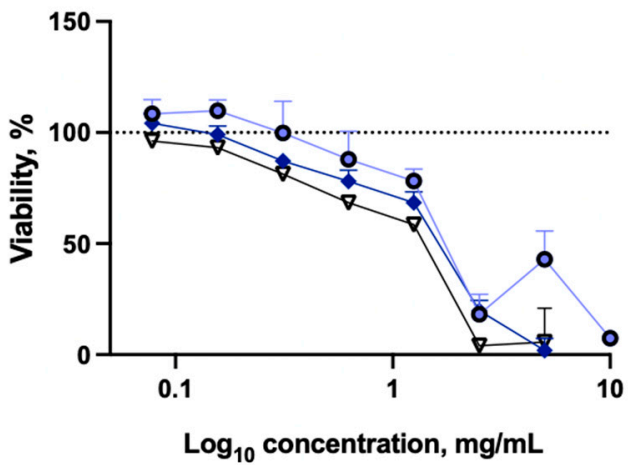

- $4 \mathrm{IC}_{50} 1.1773 \mathrm{mg} / \mathrm{mL}$

$5 \quad \mathrm{IC}_{50} 2.002 \mathrm{mg} / \mathrm{mL}$

$6 \quad \mathrm{IC}_{50} 1.362 \mathrm{mg} / \mathrm{mL}$

Figure 5. Cytotoxicity of extracts in Balb/c 3T3 cell line. Results expressed as a relative change compared to untreated control. (A) - 50\% EtOH extracts: 1-Maria Bruvele; 2-Tatiana; 3-Bot. Lub.; (B) - water extracts: 4-Tatiana; 5-Bot. Lub.; 6-Maria Bruvele. Data represented as mean \pm SD $(n=3)$. Dotted line represents the control level $(100 \%)$.

In most cases, at concentrations similar to the MIC values observed in antimicrobial activity tests, no toxic effect was observed. Water extracts were slightly more cytotoxic than ethanol extracts. An extract at a specific concentration was considered to be cytotoxic if the cell viability was reduced by more than $20 \%$. Cytotoxic concentrations of ethanol extracts ('Maria Bruvele', 'Tatiana') did not exceed the concentrations needed to inhibit the growth of the tested microorganisms. Some variations in the effects of water extracts on cell viability were observed, with the 'Tatiana' extract being less cytotoxic than the other two water extracts. Compared to other studies, extracts tested here have low cytotoxicity. Triterpenoid-rich SBT extracts have been reported to be cytotoxic to cancerous and normal human cell lines at lower concentrations than in our study, with $\mathrm{IC}_{50}$ values ranging between 14.58-74.58 $\mu \mathrm{g} / \mathrm{mL}$ [48]. SBT extract within concentration range $0.62-62 \mu \mathrm{g} / \mathrm{mL}$ was shown to have no negative effects on NIH 3T3 cell line but reduced viability of glioma 
cells in vitro. This emphasizes the variations of the effects in different cell lines [49]. At the same time, in a study by Rozalska et al., $\mathrm{IC}_{50}$ values above $1 \mathrm{mg} / \mathrm{mL}$ for phenolic SBT fractions have been reported [50]. The effects on cell lines depend on the extract production methods and chemical composition. Varying cytotoxicity data among studies might be explained mainly by the variations in chemical composition on SBT extracts.

The low concentrations needed to inhibit the growth of specific microorganisms, especially C. albicans and S. aureus, along with the absence of cytotoxicity at low concentrations, indicate on the potential of the tested extracts to be further developed for various antimicrobial applications. The low concentrations needed to inhibit the growth of specific microorganisms, especially C. albicans and S. aureus, along with the absence of cytotoxicity at low concentrations, indicate to the potential of the tested extracts to be further developed for various antimicrobial applications.

Interestingly, at low concentrations, ethanol extracts of 'Maria Bruvele' and 'Tatiana' slightly increased cell viability and proliferation (increases of 24.13 and $22.59 \%$, respectively). This phenomenon could be further researched in future studies.

\subsection{The Radical Scavenging Activity of SBT Extracts}

The radical scavenging activity of SBT extracts was evaluated by DPPH' tests, expressed as the $\mathrm{IC}_{50}$ value, the concentration required for the $50 \%$ inhibition of free radicals [51]. The results of the radical scavenging activity assays are shown in Figure 6. Among the SBT samples under study, the 50\% EtOH extracts of 'Maria Bruvele' and 'Bot. Lub.' twigs manifested the highest radical scavenging activity $\left(\mathrm{IC}_{50}=6.8 \mathrm{mg} / \mathrm{L}\right.$ and $\left.6.6 \mathrm{mg} / \mathrm{L}\right)$ compared to the other extracts.

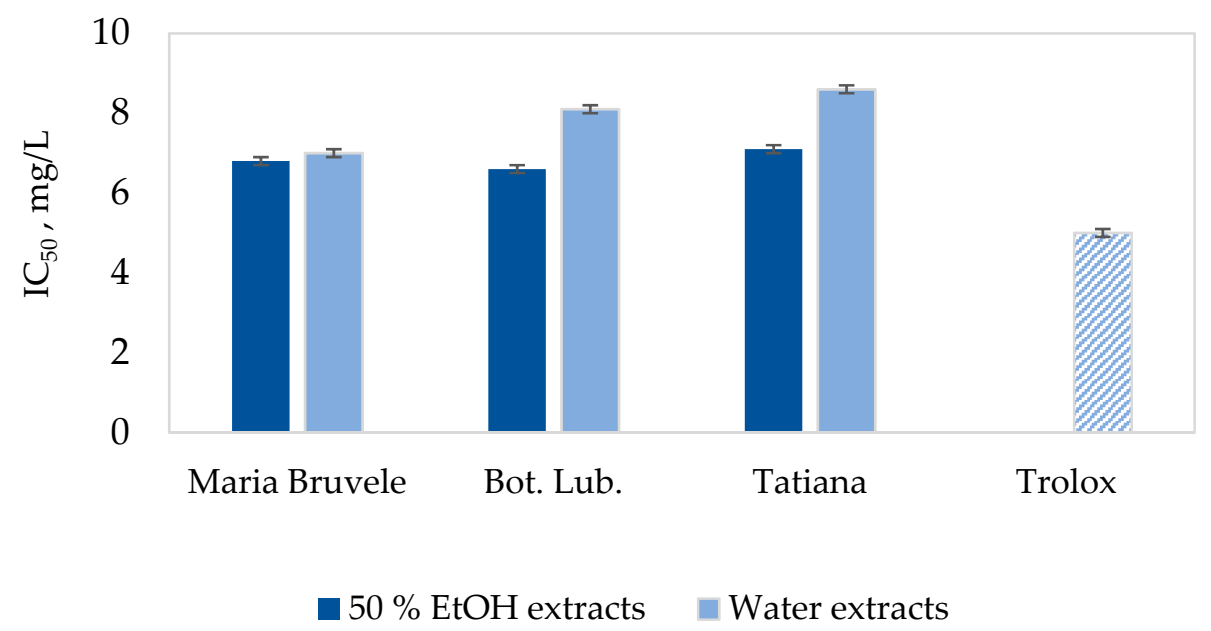

Figure 6. Radical scavenging activity of SBT biomass extracts by DPPH' test. Data represented as mean $\pm \mathrm{SD}(n=3)$.

As shown in Figure 7, such high activity of these extracts is associated with a high content of polyphenolic compounds (48 and 43 GAE g/100 g extract), including PACs (13 and $11 \%$ on the o.d. extract, $\mathrm{CI}=0.2$ at $\alpha=0.05$ ).

When comparing the radical scavenging activity of the extracts from SBT twigs, a correlation between the content of carbohydrates as unwanted compounds in the extracts and their radical scavenging activity could be observed (Figure 8). With the increase in carbohydrate content in the extracts, their radical scavenging activity decreased in the DPPH' test. The water extract of Tatjana twigs had a weaker ability to deactivate radicals due to the high content of carbohydrate impurities ( $23 \%$ on o.d. extract, $\mathrm{CI}=0.03$ at $\alpha=0.05)$ and low content of PACs (7\% on o.d. extract) in the extract. The polar groups of carbohydrate impurities can form hydrogen bonds with the hydroxyl groups of polyphenolic compounds, thus reducing their radical scavenging activity. The carbohydrate content in the $50 \% \mathrm{EtOH}$ and water extracts of SBT biomass is shown in Figure 8. 


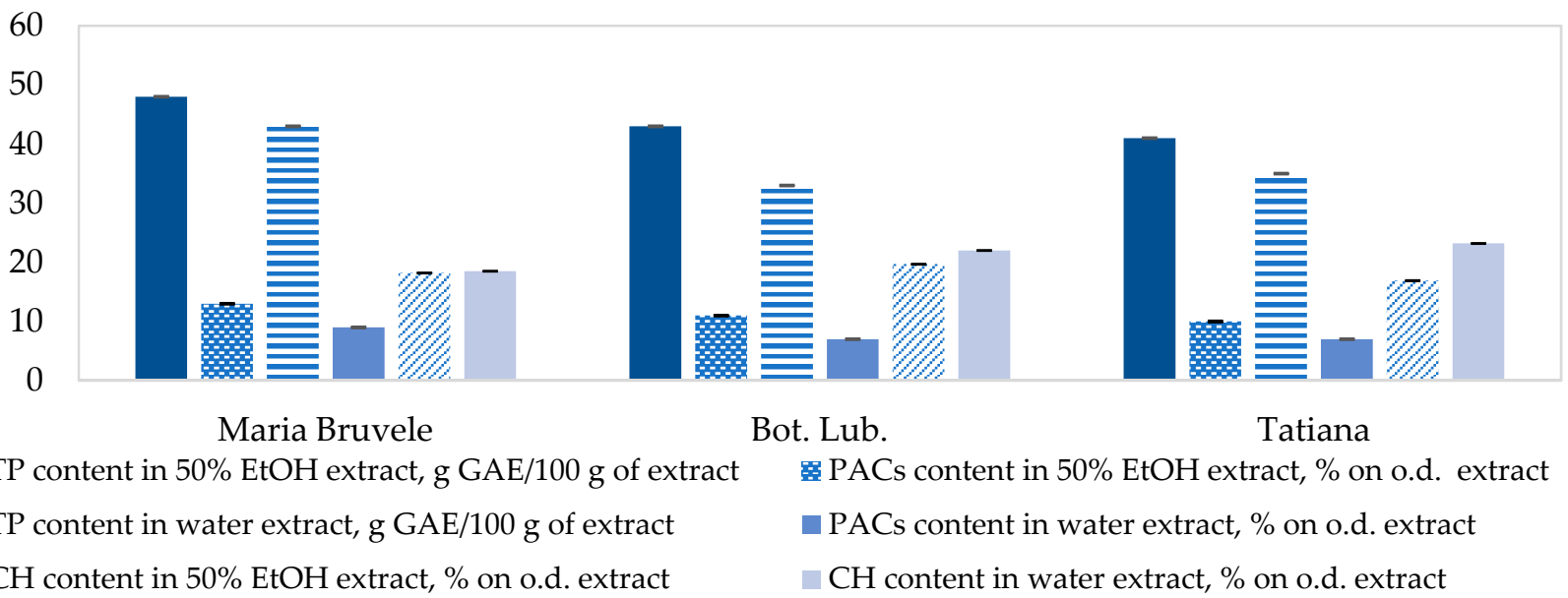

Figure 7. Chemical composition of extracts from SBT biomass. Data represented as mean \pm SD $(n=3)$.

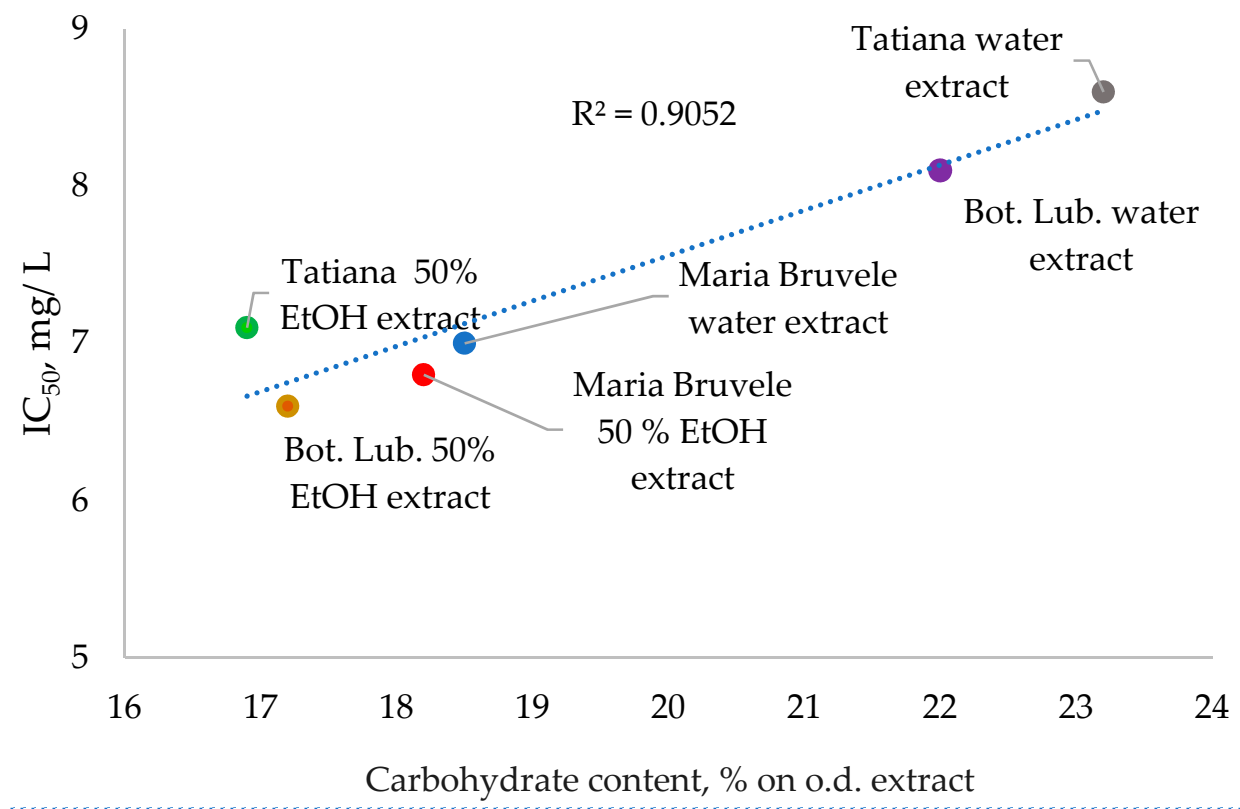

Figure 8. Effect of carbohydrate content on radical scavenging activity. Confidence intervals for antioxidant activity: $\mathrm{CI} \leq 0.1$ at $\alpha=0.05$, for carbohydrate content: $\mathrm{CI} \leq 0.03$ at $\alpha=0.05$.

One way to increase antioxidant activity is to remove impurities from the dominant components with strong antioxidant properties. Our preliminary research indicates that proanthocyanidins are powerful antioxidants. Based on this, it was decided to purify proanthocyanidins by Sephadex LH-20. As a result, two fractions were obtained, which were also characterized by UHPLC-ELS (Figure 9).

In comparison to the synthetic antioxidant Trolox as a reference, which is a watersoluble derivative of vitamin $\mathrm{E}\left(\mathrm{IC}_{50}=5 \mathrm{mg} / \mathrm{L}\right.$ in $\mathrm{DPPH}$ ' test), the $50 \% \mathrm{EtOH}$ extract of 'Bot. Lub.' and 'Maria Bruvele' showed the most promising results $\left(\mathrm{IC}_{50}=7.1 \mathrm{mg} / \mathrm{L}\right.$ in DPPH' test, $\mathrm{CI}=0.1$ at $\alpha=0.05)$. The antioxidant activity of purified procyanidin was significantly higher $\left(\mathrm{IC}_{50}=2.6 \mathrm{mg} / \mathrm{L}\right.$ in $\mathrm{DPPH}^{\cdot}$ test, $\mathrm{CI}=0.1$ at $\left.\alpha=0.05\right)$. 


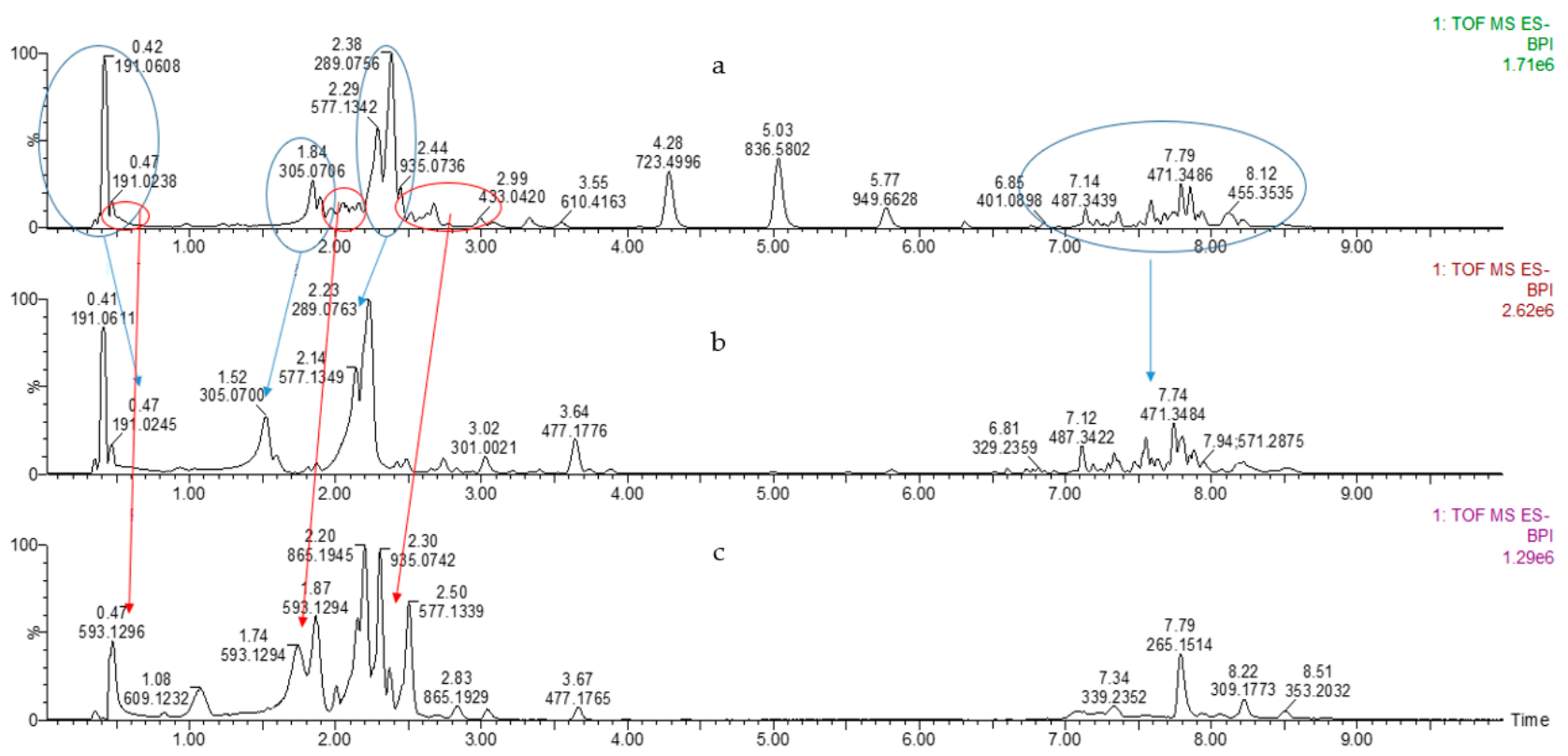

Figure 9. UHPLC-ELS chromatograms: (a) - 50\% EtOH extract of 'Maria Bruvele' biomass; (b) - low molecular compound rich fraction; (c) - procyanidin trimer rich fraction.

\subsection{The Content of Serotonin in SBT Extracts}

Of the alkaloid compounds, SBT lignocellulosic biomass contains serotonin, which is a powerful antidepressant and stimulant of psychological and physical activity. The analysis of liquid chromatography (UHPLC-ELS) proved its presence in the composition of hydrophilic extracts. The serotonin content in the SBT extracts (Figure 10) varied from 3.6 to $7.5 \%$ per dry extract, and, starting from the highest content, decreased in the following order: water extracts of 'Maria Bruvele' and 'Tatiana' > $50 \%$ EtOH extract of 'Bot. Lub.' > $50 \%$ EtOH extract of 'Maria Bruvele' > water extract of 'Bot. Lub.'.

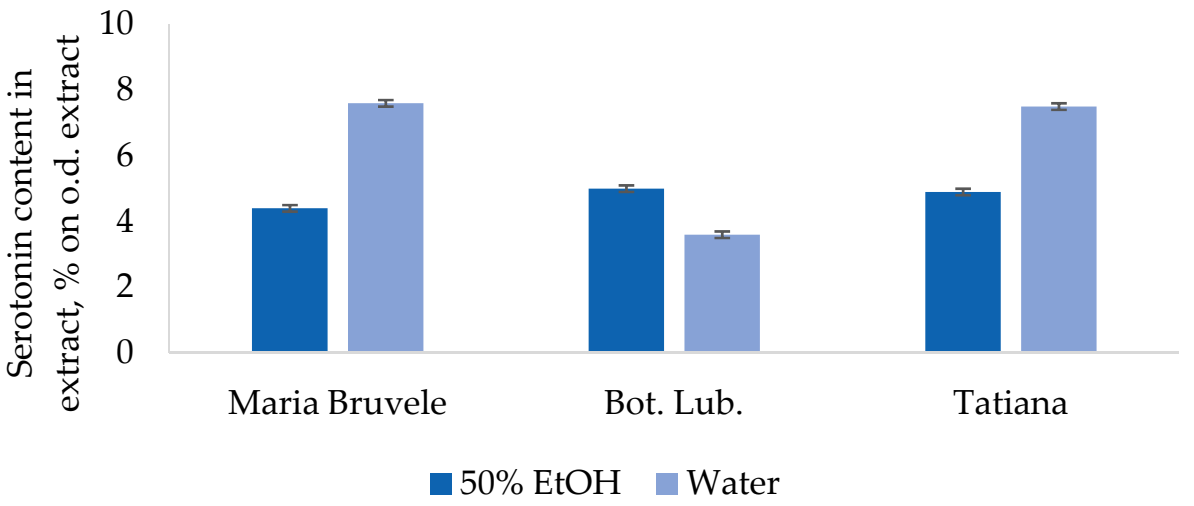

Figure 10. Content of serotonin in extracts from SBT biomass. Data presented as mean $\pm \operatorname{SD}(n=3)$. $\mathrm{CI} \leq 0.04$ at $\alpha=0.05$.

When using extracts as biologically active food additives or as an additional component of activators of food enzymes, serotonin will only increase the value of this biologically active product.

To prove the potential of the extract's biological activity, in the following stage, in vitro experiments were performed. 


\subsection{Evaluation of the Influence of the Extracts on Amylase Activity}

In vitro tests were also carried out for the evaluation of the influence of the extracts on the initial processes of human macro-metabolism, which is relevant for the extract usage for health care and disease prevention. Earlier tests in collaboration with Riga Stradinš University in this regard have revealed the beneficial effects of PACs-containing extracts on amylase activity, resulting in the acceleration of starch degradation to glucose, which could be useful for the treatment of persons with underweight, malnutrition, and malabsorption [52,53]. Under normal physiological conditions, all extracts at dosages of $100 \mu \mathrm{L}$, $500 \mu \mathrm{L}$, and $1000 \mu \mathrm{L}$ at an extract concentration of $2 \mathrm{mg} / \mathrm{L}$ showed a significant activation (two times) of amyloclastic force (AF). With the increase in the extract concentration from $2 \mathrm{mg} / \mathrm{L}$ to $20 \mathrm{mg} / \mathrm{L}$, at dosages of $100 \mu \mathrm{L}$ and $500 \mu \mathrm{L}$ of the extracts, the same activation was observed. Increased $\alpha$-amylase activation can accelerate the degradation of starch to glucose, which may be useful in the treatment of people with underweight, malnutrition, and malabsorption.

\section{Materials and Methods}

\subsection{Materials}

The twigs (without leaves) of three sea buckthorn cultivars- $H$. rhamnoides 'Maria Bruvele', 'Botanicheskaya Lubitelskaya', and 'Tatiana'-were collected from the sea buckthorn plantation area in Latvia under the same growing conditions in summer of 2020. Varieties suitable for commercial growth in the NE of Europe and Canada, larger and more juicy fruits with better taste, and fruits with significantly less troublesome stellate hairs were chosen. The twigs were dried at room temperature, ground with a knife mill (Cutting Mill SM100, Retsch, Haan, Germany) and sieved to select the particles between 1 and $4 \mathrm{~mm}$. These fractions were stored at $-8^{\circ} \mathrm{C}$.

\subsection{Isolation of the Hydrophilic Extracts from Twigs of Sea Buckthorn Biomass}

Hydrophilic extracts were isolated by the convective extraction of SBT biomass at $60{ }^{\circ} \mathrm{C}$ for $30 \mathrm{~min}$ using the following solvents: distilled water or aqueous ethanol $(1: 1, v / v)$. The extracts were freeze-dried to yield a brown solid. The yield of the extracts is presented as a percentage based on the oven-dried (o.d.) biomass.

\subsection{Total Polyphenols Content in the Extracts}

The total polyphenols (TP) content of the extracts was determined using the FolinChicolteu method using gallic acid as the standard. Amounts of $5 \mathrm{~mL}$ of $10 \%$ FolinCiocalteu reagent and $4 \mathrm{~mL}$ of $7.5 \%$ sodium carbonate solution were added to $1 \mathrm{~mL}$ of the extract. Distilled water was used instead of gallic acid as a reference solution. After $30 \mathrm{~min}$, the absorbance of the mixture was measured against a blank solution at $765 \mathrm{~nm}$ using a UV/VIS spectrometer Lambda 650 (Perkin Elmer, Shelton, CT, USA). Gallic acid was used to calibrate the standard curve. Each extract was analyzed in triplicate, and the results were expressed in grams of gallic acid per $100 \mathrm{~g}$ of extract sample (g GAE/100 g extract) [54].

\subsection{Proanthocyanidins Content in the Extracts}

The PACs content of the extracts was determined by oxidative depolymerization to anthocyanidins in acid butanol [55] using procyanidin dimer B2 as a reference compound. Amounts of $6 \mathrm{~mL}$ of acid butanol $(5 \%(v / v)$ concentrated $\mathrm{HCl}$ in $\mathrm{n}$-butanol) and $0.2 \mathrm{~mL}$ of iron reagent $(w / v)\left(\mathrm{FeNH}_{4}\left(\mathrm{SO}_{4}\right)_{2} \cdot 12 \mathrm{H}_{2} \mathrm{O}\right.$ in $\left.2 \mathrm{M} \mathrm{HCl}\right)$ were added to $1 \mathrm{~mL}$ of the extract aliquots while stirring the tube without heating and allowing it to be heated in a water bath at $80{ }^{\circ} \mathrm{C}$ for $50 \mathrm{~min}$. After $50 \mathrm{~min}$, the absorbance of the mixture was measured against a blank solution at $550 \mathrm{~nm}$ using UV/VIS spectrometer Lambda 650 (Perkin Elmer, Shelton, CT, USA). Each extract was analyzed in triplicate, and assay results were expressed as a percentage per o.d. extract. 


\subsection{Purification of PACs}

The purification of PACs from non-tannin phenolics and sugar was carried out using a Sephadex $\mathrm{LH}-20$ with $96 \% \mathrm{EtOH}$ and $70 \%(v / v)$ acetone as the respective purification solvents. In the purification process, low-molecular-weight phenolics were eluted with $96 \%$ $\mathrm{EtOH}$, and the PACs were eluted with $70 \%(v / v)$ acetone. Purified PACs were evaporated using a rotary evaporator prior to being freeze-dried and stored at $-8^{\circ} \mathrm{C}$.

\subsection{Carbohydrate Content in the Extract}

The total amounts of the carbohydrate in the extracts were determined using GC analysis after hydrolysis, reduction, and acetylation [56]. Extract hydrolysis: $0.125 \mathrm{~mL}$ of sulfuric acid was added to $10 \mathrm{mg}$ of the extract; after $45 \mathrm{~min}$, it was diluted with $3.5 \mathrm{~mL}$ of water and placed into a thermostat for $1 \mathrm{~h}$ at $121{ }^{\circ} \mathrm{C}$. After hydrolysis, the sample was neutralized with $0.32 \mathrm{~mL}$ of ammonium hydroxide solution and $0.1 \mathrm{~mL}$ of analytical standard methyl $\alpha$-D-glucose. Reduction and acetylation: $1 \mathrm{~mL}$ of borohydride solution was added to $0.2 \mathrm{~mL}$ of neutralized solution and heated for $90 \mathrm{~min}$ at $40^{\circ} \mathrm{C}$. The excess reagent was partitioned with $0.1 \mathrm{~mL}$ of concentrated acetic acid. After reduction, $2 \mathrm{~mL}$ of acetic anhydride and $0.3 \mathrm{~mL}$ of 1-methylimidazole were added. After $10 \mathrm{~min}\left(30^{\circ} \mathrm{C}\right)$, the excess acetic anhydride was partitioned with $5 \mathrm{~mL}$ of distilled water. The cooled solution was extracted once with $1 \mathrm{~mL}$ of $\mathrm{CH}_{2} \mathrm{Cl}_{2}$. The lower layer was transferred to the chromatography flask with a Pasteur pipette and stored at $-20{ }^{\circ} \mathrm{C}$ until gas chromatographic analysis. Gas chromatographic analysis was performed using an Agilent 6850 Series GS System (Agilent Technologies, Santa Clara, CA, USA): column-DB-1701; length-30 m; internal diameter$0.25 \mathrm{~mm}$; layer thickness- $0.25 \mu \mathrm{m}$.

\subsection{UHPLC-ESI-MS/MS Analysis}

Extract analysis was performed on an Acquity UPLC system (Waters Corp., Singapore) coupled with a quadrupole-time of flight (Q-TOF) MS instrument (UPLC/SYNAPT G2Si HDMS Q-TOF Mass Spectrometer, Waters, Milford, MA, USA) with an electrospray ionization (ESI) source.

The separation was carried out on a U-HPLC column $(2.1 \mathrm{~mm} \times 50 \mathrm{~mm}$ i.d., $1.7 \mu \mathrm{m}$, BEHC18) (Waters Acquity) at a flow rate $0.35 \mathrm{~mL} / \mathrm{min}$. The eluent was $0.1 \%$ formic acid, water (A), and acetonitrile (B). A gradient solvent system was used: $0-1 \mathrm{~min}, 5-20 \%$ (B); 1-5 min, 20-25\% (B); 5-6 min, 25-75\% (B), 6-7 min, 75-80\% (B), 7-8 min, 80-5\% (B), $8-10 \mathrm{~min}, 5 \%$ (B). The injection volume was $2.0 \mu \mathrm{L}$.

The major operating parameters for the Q-TOF MS were set as follows: capillary voltage, $2.5 \mathrm{kV} \mathrm{(-);} \mathrm{cone} \mathrm{voltage,} 60 \mathrm{~V}$; cone gas flow, $50 \mathrm{~L} / \mathrm{h}$; collision energy, $6 \mathrm{eV}$; source temperature, $120^{\circ} \mathrm{C}$; desolvation temperature, $350^{\circ} \mathrm{C}$; collision gas, argon; desolvation gas, nitrogen; flow rate, $500 \mathrm{~L} / \mathrm{h}$; data acquisition range, m/z 50-1.200 Da; ionization mode negative.

\subsection{Determination of the Antimicrobial Activity}

The antimicrobial activity tests of the hydrophilic extracts from the sea buckthorn twigs were performed at the Faculty of Biology, University of Latvia. To determine antimicrobial activity, several reference microbial strains, received from the Microbial Strain Collection of Latvia (MSCL), University of Latvia, were used: Pseudomonas aeruginosa MSCL 334, Staphylococcus aureus MSCL 330, Escherichia coli MSCL 332, Bacillus cereus MSCL 330, and Candida albicans MSCL 378. The evaluation of the antimicrobial activity of the plant extracts against the test cultures of microorganisms was carried out according to the method for determining the sensitivity of microorganisms to antimicrobial drugs. Antimicrobial activity was studied in 96-well plates by the two-fold serial broth microdilution method [49], which allowed the determination of the minimum inhibitory (MIC) and minimum bactericidal/fungicidal concentrations (MBC/MFC). The MIC was determined as the lowest concentration of the studied material, which showed no visible growth. From wells where 
growth was not detected, $4 \mu \mathrm{L}$ of medium was seeded on an appropriate solidified medium for MBC/MFC determination. The test was performed in triplicate.

\subsection{Cell Line and Cultivation}

The BALB/c 3T3 murine fibroblast cell line was obtained from ATCC (American Type Culture Collection). Cells were propagated in DMEM medium (Sigma, D6046, Irvine, UK) supplemented with $1 \%$ penicillin $(100 \mathrm{U} / \mathrm{mL})$-streptomycin $(100 \mu \mathrm{g} / \mathrm{mL})$ and $10 \%$ calf serum (Sigma, C8056, St Louis, MO, USA). All cultivations were performed in a humidified $5 \% \mathrm{CO}_{2}$ atmosphere at $37^{\circ} \mathrm{C}$.

\subsection{Cytotoxicity Assay}

The cytotoxicity of the extracts was tested for the BALB/c3T3 cell line by the neutral red (NR) uptake assay. Cells were seeded in 96-well plates at a density of $5 \times 10^{3}$ cells per well. After $24 \mathrm{~h}$ of incubation, extracts in a concentration range of 0.078 to $10 \mathrm{mg} / \mathrm{mL}$ were added. Dilutions were made in a cell cultivation medium. Cultivation in the presence of extracts was performed for $48 \mathrm{~h}$. Afterwards, the plates were washed with phosphatebuffered saline (PBS) (Sigma, D8537, Irvine, UK), and $25 \mu \mathrm{g} / \mathrm{mL}$ NR solution (Sigma, N2889, Irvine, UK) diluted in 5\% fetal calf serum containing media was added. After $3 \mathrm{~h}$ incubation in a humidified $5 \% \mathrm{CO}_{2}$ atmosphere at $37^{\circ} \mathrm{C}$, the plate was washed with PBS, and the NR taken up by viable cells was extracted using desorbing fixative (50\% ethanol $/ 1 \%$ acetic acid $/ 49 \%$ water). Absorbance at $540 \mathrm{~nm}$ was measured using a Tecan M200 Infinite Pro microplate reader (Tecan, Switzerland). Cytotoxicity was expressed as a concentration-dependent reduction in the uptake of NR, compared to the untreated controls, and the $\mathrm{IC}_{50}$ value for each compound was calculated using GraphPad 9 software. The cell line and test method complied with OECD guidelines [57].

\subsection{Determination of the Radical Scavenging Activity}

Hydrophilic extracts were tested for their radical scavenging activity against the DPPH' assay [51] using UV/VIS spectrometer Lambda 650 (Perkin Elmer, Shelton, CT, USA). The free radical scavenging activity is expressed as the concentration of antioxidant, $\mathrm{mg} / \mathrm{L}$, required for a $50 \%$ inhibition of the free radicals $\left(\mathrm{IC}_{50}\right)$. The lower the $\mathrm{IC}_{50}$ value, the higher the radical scavenging activity of the compounds.

\subsection{In Vitro Test of the Alpha-Amylase Activity}

In vitro tests of the hydrophilic extracts from sea buckthorn samples were performed at the Department of Human Physiology and Biochemistry of Riga Stradinš University based on the determination of amyloclastic force by starch-iodine color assay $[53,54]$. The saliva used for research was donated on a volunteer basis by a group of students with no record of chronic or acute illnesses. The students were non-smokers, as smoking can increase amylase activity [58]. Any sporting or other serious physical activity was stopped $48 \mathrm{~h}$ before the experiment according to the protocol [59]. No chewing gum was allowed. No alcohol or caffeine was taken $18 \mathrm{~h}$ before the experiment, and the last meals and soft drinks with low $\mathrm{pH}$ were $2 \mathrm{~h}$ before the examination to obtain clean results.

The extracts were tested in the doses from $100 \mu \mathrm{L}$ to $500 \mu \mathrm{L}$ at a concentration of extracts from $2 \mathrm{mg} / \mathrm{L}$ to $20 \mathrm{mg} / \mathrm{L}$. The influence of the extracts on salivary amylase was measured by the breakdown of polysaccharides containing linear $\alpha-1,4$ glucose bonds in starch. The amylase activity was characterized by the amyloclastic force (AF), that is, the volume of the $0.1 \%$ starch solution in milliliters that is hydrolyzed by $1 \mathrm{~mL}$ of saliva in the test tubes at $38{ }^{\circ} \mathrm{C}$ for $30 \mathrm{~min}$. Then, $1 \%$ iodine solution was added (as a marker for the presence of starch by color changes). The amyloclastic force is denoted as $\mathrm{D}_{30 / 38^{\circ}}$. The average range of $\mathrm{AF}$ for a healthy person is from 320 to 1280. Saliva without extract was used as a reference. The amyloclastic force of the reference sample was $\mathrm{D}_{30 / 38^{\circ}} 640$. 


\subsection{Statistical Analysis}

All measurements were conducted in triplicate, and the results are presented as the mean value \pm standard deviation (SD). Statistical analyses were performed using Microsoft Excel 2016. Confidence intervals for a mean using a Student's T distribution were calculated at a significance level $\alpha=0.05$. The correlation is presented by the Pearson coefficient. A significance level of $p<0.05$ was used.

\section{Conclusions}

The chemical composition of the water and ethanol extracts from the SBT biomass of three prospective cultivars, $H$. rhamnoides 'Maria Bruvele', 'Tatiana', and 'Botanicheskaya Lubitelskaya', was determined for the first time. The results of UHPLC-ELS chromatograms showed that the extracts of SBT are rich in polyphenolic compounds, such as quinic acid, PAC monomers and oligomers, which predetermines their radical scavenging activity. Maria Bruvele twigs biomass has the highest content of phenolic compounds in the $50 \%$ EtOH extract (48 GAE g/100 g extract).

The 50\% EtOH extracts of 'Maria Bruvele' and 'Botanicheskaya Lubitelskaya' twigs showed the most promising results for radical scavenging activity $\left(\mathrm{IC}_{50}=6.8 \mathrm{mg} / \mathrm{L}\right.$ and $6.6 \mathrm{mg} / \mathrm{L}$, in the DPPH' test) compared to the other extracts. This could be connected to the higher content of polyphenolic compounds (48 and $43 \mathrm{GAE} g / 100 \mathrm{~g}$ extract), including PACs (13 and $11 \%$ on the o.d. extract). These extract properties can be valuable not only in the creation of pharmaceuticals on the basis of plant secondary metabolites, but also in the food and cosmetics industries to slow down the oxidative processes occurring in raw materials and finished products at different stages of the technological process during storage.

Among the three varieties of SBT, 'Maria Bruvele' 50\% EtOH extract's antimicrobial activity in suppressing the pathogenic bacteria and yeast is the highest, and its effectiveness against bacteria is comparable with that of some of the synthetic antibiotics. This could be explained by the high content of quinic acid, gallocatechin, isomer epigallocatechin, (epi)catechin-(epi)gallocatechin, and proanthocyanidins in the 'Maria Bruvele' extract and their possible synergetic activity. These results provide the scope of further research on the SBT extracts for applications in the prevention and treatment of infectious diseases. At concentrations similar to the MIC values observed in antimicrobial activity tests, no toxic effect was observed, thus confirming the potential for practical use of the extracts.

The serotonin content in the SBT extracts varied from 3.6 to $7.5 \%$ per dry extract, and, starting from the highest content, decreased in the following order: water extracts of 'Maria Bruvele' and 'Tatiana' $>50 \%$ EtOH extract of 'Bot. Lub.' $>50 \%$ EtOH extract of 'Maria Bruvele' > water extract of 'Bot. Lub.'. As the serotonin content of $4-6 \%$ per dry extract is already considered in the literature as high, these results are very promising for obtaining serotonin preparations on the basis of SBT. The discovery of mammalian neurohormones in plants provides new avenues for the investigation of medicinally active compounds. There is a lack of research on the effects of serotonin. As SBT is a very stress-resistant plant, it would be very interesting to explore if serotonin additives would help to improve similar characteristics in the human body. Currently, the concept of the influence of the gut microbiota on the central nervous system is gaining ground and building evidence. In this case, serotonin in the digestive system could affect mood and brain health. Further research on serotonin effects is planned.

In vitro tests carried out for the evaluation of the influence of the extracts on the initial processes of human macro-metabolism, presented by saliva amylase activity, showed that under normal physiological conditions, all extracts have a significant activation (two times higher than the reference) of amyloclastic force (AF). These results are very promising for the treatment of people with underweight, malnutrition, and malabsorption. The effect of combined SBT extracts on amylase activation and serotonin anti-depression and physical activity improvement could also be beneficial. 
The results of this research showed that the biomass of the cultivars under study has high biological activity and nutraceutical and pharmaceutical potential, and the creation of a wasteless biorefinery processing scheme for SBT sustainable production including both berries and biomass applications is possible and prospective. SBT acreage is evaluated as $3 \mathrm{mln}$ ha in 2017 [8], and average crop productivity is $\sim 4-5 \mathrm{t} / \mathrm{ha}[1,8,9]$, that is, potentially $13,5 \mathrm{mln} t$ annually. Considering that biomass volume, as mentioned above, comprises $\sim 12-15 \%$ of berries, an average volume of biomass could be $\sim 2 \mathrm{mln}$ t yearly. The potential contribution of twigs to the market values will depend on the ways of application: as a raw biomass, as an extract, as a group of compounds, or as purified compounds. On the example of PACs, considering the average for all cultivars yield of extracts of $23 \%$, average yield of PACs $10 \%$ on o.d. biomass, and the very approximate price for raw material $10 \mathrm{EUR} / \mathrm{kg}$ [60], the market value for PACs could be very roughly estimated as EUR 480 million annually. However, if to calculate on the basis of the final product packed as biologically active additives and sold, e.g., on iHerb [61] then the price could reach $5700 \mathrm{EUR} / \mathrm{kg}$, and the market value theoretically could increase up to EUR 260 billion annually. That would be a hardly achievable figure considering the worldwide market value, the global health and wellness market is forecast to be worth one-trillion dollars by 2026 [62]. The theoretical figures would increase even more if we take, for example, analytical standard serotonin as a basis for calculation. However, the demand for the product, possible market share, possibilities of compounds purification, and other important market and technological factors have to be considered. In addition, today not all wild plantations are used for industrial berries collection, and the amount of SBT biomass could be approximately 4 times less [63], correspondingly. For more precise market value data, a separate, more profound research is necessary which is not the aim of this article. However, even such rough calculations show that SBT biomass contribution to the market is comparable with berries market value.

The evaluation of the best harvesting time and possibilities for the use of SBT biomass for the pruning of shrubs, as well as the comparison of seasonal changes in the phytochemical profile and biological activity of hydrophilic extracts, will be performed in further research.

Author Contributions: All authors (S.J., A.A., L.L., O.B., V.N., L.J., N.Z., G.T., M.S., G.R., A.R.-S. and J.K.) have made a substantial, direct and intellectual contribution to the work, and approved it for publication. Conceptualization, S.J., A.A. and G.T.; methodology, S.J., A.A., G.T., O.B., A.R.-S., J.K. and V.N.; investigation, S.J., A.A., L.L., O.B., V.N., L.J., N.Z., G.T., M.S., G.R., A.R.-S. and J.K.; resources, N.Z. and G.R.; data curation, S.J., A.A. and G.T.; writing-original draft preparation, S.J., A.A. and G.T.; writing—review and editing, S.J., A.A., L.L., O.B., V.N., L.J., N.Z., M.S., G.R., A.R.-S. and J.K.; visualization, S.J. and A.A.; project administration, G.T. and S.J.; funding acquisition, G.T., A.A., G.R. and S.J. All authors have read and agreed to the published version of the manuscript.

Funding: This research was funded by ERDF project nr. Nr.1.1.1.1/19/A/146 “Biorefinery processing of sea buckthorn non-fruit biomass using innovative techniques and comprehensive analytical investigation, for obtaining prospective for Latvian bioeconomy high value-added products, including serotonin".

Data Availability Statement: Data are contained within the article.

Acknowledgments: ERDF project nr. Nr.1.1.1.1/19/A/146 “Biorefinery processing of sea buckthorn non-fruit biomass using innovative techniques and comprehensive analytical investigation, for obtaining prospective for Latvian bioeconomy high value-added products, including serotonin" is greatly acknowledged. The authors would like to express their gratitude to Andrejs Bruvelis from SIA “BRUwell (Latvia) for his deep knowledge about sea buckthorn, and his team for kindly providing the SBT biomass samples.

Conflicts of Interest: The authors declare no conflict of interest. Ekokompozit Ltd. declares no conflict of interest with this paper. 


\section{References}

1. Gâtlan, A.M.; Gutt, G. Sea Buckthorn in Plant Based Diets. An Analytical Approach of Sea Buckthorn Fruits Composition: Nutritional Value, Applications, and Health Benefits. Int. J. Environ. Res. Public Health 2021, 18, 8986. [CrossRef] [PubMed]

2. Ruan, C.; Li, D. Community characteristics of Hippophae rhamnoides forest and water and nutrient condition of the woodland in Loess Hilly Region. Chin. J. Appl. Ecol. 2002, 13, 1061-1064.

3. Tkacz, K.; Wojdyło, A.; Piotr, I.; Turkiewicz, P.N. Triterpenoids, phenolic compounds, macro- and microelements in anatomical parts of sea buckthorn (Hippophaë rhamnoides L.) berries, branches and leaves. J. Food Composit. Analys. 2021, 103, 104107. [CrossRef]

4. Seabuckwonders. Available online: https://www.seabuckwonders.com/pages/what-is-sea-buckthorn (accessed on 24 January 2022).

5. TRIDGE. Available online: https://www.tridge.com/intelligences/sea-buckthron/price (accessed on 24 January 2022).

6. Guliyev, V.B.; Gul, M.; Yildirim, A. Hippophae rhamnoides L.: Chromatographic methods to determine chemical composition, use in traditional medicine and pharmacological effects. J. Chromatogr. B 2004, 812, 291-307. [CrossRef]

7. Changeua. Available online: https:// changeua.com/business/mirovoy-ryinok-oblepihi-otsenivaetsya-v-1-mlrd (accessed on 24 January 2022).

8. Stobdan, T.; Phunchok, T. Value Chain Analysis of Seabuckthorn (Hippophae rhamnoides L.) in Leh Ladakh; Ministry of Agriculture and farmer Welfare, Government of India: New Dehli, India, 2017.

9. Bruvelis, A. Experiences about sea buckthorn cultivation and harvesting in Latvia. In Producing Sea Buckthorn of High Quality, Proceedings of the 3-rd European Workshop on Sea Buckthorn EuroWorkS 2014, Naantali, Finland, 14-16 October 2014; Kauppinen, S., Petruneva, E., Eds.; Natural Resources Institute: Helsinki, Finland, 2015; pp. 36-41.

10. Musayev, M.K. Agro-ecological characteristics of sea buckthorn (Hippophae rhamnoides L.) in Azerbaijan. J. Crop Weed 2013, 9, 114-120.

11. Letchamo, W.; Ozturk, M.; Altay, V.; Musayev, M.; Mamedov, N.A.; Hakeem, K.R. An Alternative Potential Natural Genetic Resource: Sea Buckthorn [Elaeagnus Rhamnoides (Syn.: Hippophae rhamnoides)]. In Global Perspectives on Underutilized Crops; Ozturk, M., Hakeem, K.R., Ashraf, M., Ahmad, M.S.A., Eds.; Springer: Cham, Switzerland, 2018; pp. 25-82. [CrossRef]

12. Criste, A.; Urcan, A.C.; Bunea, A.; Pripon Furtuna, F.R.; Olah, N.K.; Madden, R.H.; Corcionivoschi, N. Phytochemical Composition and Biological Activity of Berries and Leaves from Four Romanian Sea Buckthorn (Hippophae rhamnoides, L.) Varie-ties. Molecules 2020, 25, 1170. [CrossRef]

13. Klovāne, I. Sea Buckthorn in the Starting Line. Famous Healthy Berry Growers Share Experiences. LA.LV News. 27 June 2014 Available online: https:/ / www.la.lv/smiltserkski-starta-taisne-pieredze (accessed on 24 November 2021).

14. BRUwell. Available online: http:/ / www.bruwell.lv/en/ (accessed on 24 January 2022).

15. Klovāne, I. Smiltsērkšḳi ar lieliem augliem. LA.LV News, 27 June 2014. Available online: https:/ / www.la.lv/smiltserkski-arlieliem-augliem-2 (accessed on 24 November 2021).

16. Tkacz, K.; Wojdyło, A.; Turkiewicz, I.P.; Ferreres, F.; Moreno, D.A.; Nowicka, P. UPLC-PDA-Q/TOF-MS profiling of phenolic and carotenoid compounds and their influence on anticholinergic potential for AChE and BuChE inhibition and on-line antioxidant activity of selected Hippophaë rhamnoides L. cultivars. Food Chem. 2020, 309, 125766. [CrossRef]

17. Tkacz, K.; Wojdyło, A.; Turkiewicz, I.P.; Bobak, Ł.; Nowicka, P. Anti-Oxidant and Anti-Enzymatic Activities of Sea Buckthorn (Hippophaë rhamnoides L.) Fruits Modulated by Chemical Components. Antioxidants 2019, 8, 618. [CrossRef] [PubMed]

18. Vilas-Franquesa, A.; Saldo, J.; Juan, B. Potential of Sea Buckthorn-Based Ingredients for the Food and Feed Industry-A Review. Food Prod. Proc. Nutr. 2020, 2, 17. [CrossRef]

19. Chen, L.; Xin, X.; Yuan, Q.; Su, D.; Liu, W. Phytochemical Properties and Antioxidant Capacities of Various Colored Berries. J. Sci. Food Agric. 2014, 94, 180-188. [CrossRef]

20. Zompra, A.A.; Chasapi, S.A.; Karagkouni, E.C.; Karamouzi, E.; Panopoulos, P.; Spyroulias, G.A. Metabolite and Bioactive Compounds Profiling of Meteora Sea Buckthorn Berries through High-Resolution NMR Analysis. Metabolites 2021, 11, 822. [CrossRef]

21. Application of sea-buckthorn fruit oil and sea-buckthorn leaf in preparing medicine for treating depression. Chinese Patent CN1772032B, 4 May 2011. Available online: https:/ / patents.google.com/patent/CN1772032B/en (accessed on 24 January 2022).

22. Chiocchio, I.; Mandrone, M.; Tomasi, P.; Marincich, L.; Poli, F. Plant Secondary Metabolites: An Opportunity for Circular Economy. Molecules 2021, 26, 495. [CrossRef] [PubMed]

23. Yadav, A.; Stobdan, T.; Chauhan, O.P.; Dwivedi, S.K.; Chaurasia, O.P. Sea Buckthorn: A Multipurpose Medicinal Plant from Upper Himalayas. In Medicinal Plants; Joshee, N., Dhekney, S.A., Parajuli, P., Eds.; Springer: Cham, Switzerland, 2019 ; pp. 399-426. [CrossRef]

24. Zielińska, A.; Nowak, I. Abundance of active ingredients in sea-buckthorn oil. Lip. Health Dis. 2017, 16, 95. [CrossRef] [PubMed]

25. Olas, B.; Skalski, B.; Ulanowska, K. The Anticancer Activity of Sea Buckthorn [Elaeagnus Rhamnoides (L.) A. Nelson]. Front. Pharmacol. 2018, 9, 232. [CrossRef]

26. Fortune Business Insights. Available online: https://www.fortunebusinessinsights.com/sea-buckthorn-market-103197 (accessed on 24 January 2022).

27. Phytochemical Investigations on Sea Buckthorn Juice Enriched with Pomace. Available online: https://www.semanticscholar. org/paper / PHYTOCHEMICAL-INVESTIGATIONS-ON-SEA-BUCKTHORN-JUICE-Rentsendavaa-Simon-Sarkadi/966b5e9 90beaa095a68c3d97887e2c077f148d7b\#related-papers (accessed on 24 January 2022).

28. Brad, I.; Vlasceanu, G.A.; Brad, I.L.; Manea, S.T. Characterization of sea buckthorn fruits and copses in terms of serotonin and microelements. Innov. Rom. Food Biotechnol. 2007, 1, 24-30. 
29. El-Merahbi, R.; Löffler, M.; Mayer, A.; Sumara, G. The roles of peripheral serotonin in metabolic homeostasis. FEBS Lett. 2015, 589, 1728-1734. [CrossRef] [PubMed]

30. Kaur, H.; Mukherjee, S.; Baluska, F.; Bhatla, S. Regulatory roles of serotonin and melatonin in abiotic stress tolerance in plants. Plant Signal. Behav. 2015, 10, e1049788. [CrossRef]

31. Ishihara, A.; Hashimoto, Y.; Miyagawa, H.; Wakasa, K. Induction of serotonin accumulation by feeding of rice striped stem borer in rice leaves. Plant Signal. Behav. 2008, 3, 714-716. [CrossRef]

32. Munster, A. The immunological answer to traumas and burns. Am. J. Med. 1984, 76, 142-145. [CrossRef]

33. Kang, K.; Kim, Y.S.; Park, S.; Back, K. Senescence-induced serotonin biosynthesis and its role in delaying senescence in rice leaves. Plant Physiol. 2009, 150, 1380-1393. [CrossRef]

34. Jenkins, T.A.; Nguyen, J.C.; Polglaze, K.E.; Bertrand, P.P. Influence of Tryptophan and Serotonin on Mood and Cognition with a Possible Role of the Gut-Brain Axis. Nutrients 2016, 8, 56. [CrossRef]

35. MedTech Europe. Available online: https://www.medtecheurope.org/amr-and-hais/ (accessed on 24 January 2022).

36. Macedo, J.L.S.; Santos, J.B. Bacterial and fungal colonization of burn wounds. Mem. Inst. Oswaldo Cruz 2005, 100, 535-539. [CrossRef] [PubMed]

37. Adamczak, A.; Ożarowski, M.; Karpiński, T.M. Antibacterial Activity of Some Flavonoids and Organic Acids Widely Distributed in Plants. J. Clin. Med. 2019, 9, 109. [CrossRef] [PubMed]

38. Lu, L.; Zhao, Y.; Yi, G.; Li, M.; Liao, L.; Yang, C.; Cho, C.; Zhang, B.; Zou, K.; Chen, Q. Quinic acid: A potential antibiofilm agent against clinical resistant Pseudomonas aeruginosa. Chin. Med. 2021, 16, 72. [CrossRef]

39. Gonçalves, R.; Mateus, N.; de Freitas, V. Inhibition of $\alpha$-Amylase Activity by Condensed Tannins. Food Chem. 2011, 125, 665-672. [CrossRef]

40. Janceva, S.; Andersone, A.; Lauberte, L.; Telysheva, G.; Krasilnikova, J.; Nokalne, I.; Janceva, J. Influence of Extracts from Bark of Deciduous Trees on the Activity of the Amylolytic Enzyme-Alpha Amylase. KEM 2021, 903, 34-39. [CrossRef]

41. Peyrot des Gachons, C.; Breslin, P.A.S. Salivary Amylase: Digestion and Metabolic Syndrome. Curr. Diabetes Rep. 2016, 16, 102. [CrossRef] [PubMed]

42. Nakajima, K.; Nemoto, T.; Muneyuki, T.; Kakei, M.; Fuchigami, H.; Munakata, H. Low serum amylase in association with metabolic syndrome and diabetes: A community-based study. Cardiovasc. Diabetol. 2011, 10, 112-121. [CrossRef]

43. Choi, Y.J.; Nam, Y.S.; Yun, J.M.; Park, J.H.; Cho, B.L.; Son, H.Y.; Kim, J.I.; Yun, J.W. Association between salivary amylase (AMY1) gene copy numbers and insulin resistance in asymptomatic Korean men. Diabetic Med. 2015, 32, 1588-1595. [CrossRef]

44. Kreps, F.; Tobolková, B.; Ciesarová, Z.; Potočňáková, M.; Janotková, L.; Schubertova, S.; Ház, A.; Schmidt, S.; Jablonsky, M. Total content of polyphenols, flavonoids, rutin, and antioxidant activity of sea buckthorn juice. BioResources $2021,16,4743-4751$. [CrossRef]

45. Janceva, S.; Lauberte, L.; Dizhbite, T.; Krasilnikova, J.; Telysheva, G.; Dzenis, M. Protective Effects of Proanthocyanidins Extracts from the Bark of Deciduous Trees in Lipid Systems. Holzforschung 2017, 71, 675-680. [CrossRef]

46. Janceva, S.; Andersone, A.; Lauberte, L.; Telysheva, G.; Bruvelis, A. Bark and twigs of Sea Buckthorn Cultivars Growing in Latvia as a Source of Natural Antioxidants. In Proceedings of the Riga Technical University 62nd International Scientific Conference, Riga, Latvia, 14-16 October 2021; p. 27.

47. Qaiyumi, S. Antimicrobial Susceptibility Testing Protocols; Schwalbe, R., Steele-Moore, L., Goodwin, A.C., Eds.; CRC Press: London, UK; New York, NY, USA, 2007. [CrossRef]

48. Marciniak, B.; Kontek, R.; Żuchowski, J.; Stochmal, A. Novel Bioactive Properties of Low-Polarity Fractions from Sea-Buckthorn Extracts (Elaeagnus Rhamnoides (L.) A. Nelson)—(In Vitro). Biomed. Pharmacother. 2021, 135, 111141. [CrossRef] [PubMed]

49. Kim, S.-J.; Hwang, E.; Yi, S.S.; Song, K.D.; Lee, H.-K.; Heo, T.-H.; Park, S.-K.; Jung, Y.J.; Jun, H.S. Sea Buckthorn Leaf Extract Inhibits Glioma Cell Growth by Reducing Reactive Oxygen Species and Promoting Apoptosis. Appl. Biochem. Biotechnol. 2017, 182, 1663-1674. [CrossRef] [PubMed]

50. Różalska, B.; Sadowska, B.; Żuchowski, J.; Więckowska-Szakiel, M.; Budzyńska, A.; Wójcik, U.; Stochmal, A. Phenolic and Nonpolar Fractions of Elaeagnus Rhamnoides (L.) A. Nelson Extracts as Virulence Modulators-In Vitro Study on Bacteria, Fungi, and Epithelial Cells. Molecules 2018, 23, 1498. [CrossRef]

51. Dizhbite, T.; Telysheva, G.; Jurkjane, V.; Viesturs, U. Characterization of the radical scavenging activity of lignins--natural antioxidants. Biores. Technol. 2004, 95, 309-317. [CrossRef] [PubMed]

52. Krasilnikova, J.; Telysheva, G.; Dizhbite, T. Assessment of lignin on saliva activity. In Proceedings of the Riga Stradins University Scientific Conference, Riga, Latvia, 29-30 March 2012; p. 143.

53. Krasilnikova, J.; Mueller-Werkmeister, H.; Feuerriegel, G.; Haunreiter, F. Influence of Lignin Extract on the Activity of Enzymes, Related to Carbohydrate and Peptide Digestion. COST Action CM0804: Chemical Biology with Natural Products; GISAP: Medical Science, Pharmacology, Part 1; International Academy of Science and Higher Education: London, UK, 2013 ; pp. 5-8.

54. Kupina, S.; Fields, C.; Roman, M.C.; Brunelle, S.L. Determination of Total Phenolic Content Using the Folin-C Assay: SingleLaboratory Validation, First Action 2017.13. J. AOAC Int. 2018, 101, 1466-1472. [CrossRef] [PubMed]

55. Shay, P.E.; Trofymow, J.A.; Constabel, C.P. An improved butanol-HCl assay for quantification of water-soluble, acetone:methanolsoluble, and insoluble proanthocyanidins (condensed tannins). Plant Methods 2017, 1-11. [CrossRef] [PubMed]

56. Blakeney, A.; Blakeney, A.B.; Harris, P.J.; Henry, R.J.; Stone, B.A. A simple and rapid preparation of alditol acetates for monosaccharide analysis. Carbohydr. Res. 1983, 113, 291-299. [CrossRef] 
57. The Organisation for Economic Cooperation and Development (OECD). Available online: https://www.oecd.org/officialdocuments/ publicdisplaydocumentpdf/?cote=env/jm/mono(2010)20\&doclanguage=en (accessed on 17 January 2013).

58. Dubick, M.A.; Conteas, C.N.; Billy, H.T.; Majumdar, A.P.; Geokas, M.C. Raised serum concentrations of pancreatic enzymes in cigarette smokers. Gut 1987, 28, 330-335. [CrossRef]

59. Nater, U.M.; La Marca, R.; Erni, K.; Ehlert, U. Alpha-Amylase Activity in Blood Increases after Pharmacological, But Not Psychological, Activation of the Adrenergic System. PLoS ONE 2015, 10, e0130449. [CrossRef]

60. Alibaba. Available online: https://www.alibaba.com/showroom/proanthocyanidin-price.html (accessed on 17 February 2022 ).

61. Iherb. Available online: https:/ / www.iherb.com (accessed on 12 January 2022).

62. Statista. Available online: https://www.statista.com/topics/3731/health-and-wellness-food-trends-in-europe (accessed on 17 February 2022).

63. Pascoe, S. Advancing British Sea Buckthorn. A Nuffield Farming Scholarships Trust Report; The Nuffield Farming Scholarships Trust: Taunton, UK, 2016. 